\title{
HFSE-REE Transfer Mechanisms During Metasomatism of a Late Miocene Peraluminous Granite Intruding a Carbonate Host (Campiglia Marittima, Tuscany)
}

\author{
Gabriele Paoli ${ }^{1, *(\mathbb{D}}$, Andrea Dini ${ }^{2}$, Maurizio Petrelli ${ }^{3}{ }^{-}$and Sergio Rocchi ${ }^{1}$ \\ 1 Department of Earth Sciences, University of Pisa, Via Santa Maria 53, 56126 Pisa, Italy; sergio.rocchi@unipi.it \\ 2 Institute of Geosciences and Georisorse-CNR, Via Moruzzi 1, 56124 Pisa, Italy; a.dini@igg.cnr.it \\ 3 Department of Physics and Geology, University of Perugia, University Square, 1, 06123 Perugia, Italy; \\ maurizio.petrelli@unipg.it \\ * Correspondence: gabriele.paoli@unipi.it or gabrielepaoli88@gmail.com
}

Received: 21 August 2019; Accepted: 1 November 2019; Published: 4 November 2019

\begin{abstract}
The different generations of calc-silicate assemblages formed during sequential metasomatic events make the Campiglia Marittima magmatic-hydrothermal system a prominent case study to investigate the mobility of rare earth element (REE) and other trace elements. These mineralogical assemblages also provide information about the nature and source of metasomatizing fluids. Petrographic and geochemical investigations of granite, endoskarn, and exoskarn bodies provide evidence for the contribution of metasomatizing fluids from an external source. The granitic pluton underwent intense metasomatism during post-magmatic fluid-rock interaction processes. The system was initially affected by a metasomatic event characterized by circulation of K-rich and $\mathrm{Ca}(-\mathrm{Mg})$-rich fluids. A potassic metasomatic event led to the complete replacement of magmatic biotite, plagioclase, and ilmenite, promoting major element mobilization and crystallization of $\mathrm{K}$-feldspar, phlogopite, chlorite, titanite, and rutile. The process resulted in significant gain of $\mathrm{K}, \mathrm{Rb}$, $\mathrm{Ba}$, and $\mathrm{Sr}$, accompanied by loss of $\mathrm{Fe}$ and $\mathrm{Na}$, with metals such as $\mathrm{Cu}, \mathrm{Zn}, \mathrm{Sn}, \mathrm{W}$, and $\mathrm{Tl}$ showing significant mobility. Concurrently, the increasing fluid acidity, due to interaction with Ca-rich fluids, resulted in a diffuse Ca-metasomatism. During this stage, a wide variety of calc-silicates formed (diopside, titanite, vesuvianite, garnet, and allanite), throughout the granite body, along granite joints, and at the carbonate-granite contact. In the following stage, Ca-F-rich fluids triggered the acidic metasomatism of accessory minerals and the mobilization of high-field-strength elements (HFSE) and REE. This stage is characterized by the exchange of major elements ( $\mathrm{Ti}, \mathrm{Ca}, \mathrm{Fe}, \mathrm{Al}$ ) with HFSE and REE in the forming metasomatic minerals (i.e., titanite, vesuvianite) and the crystallization of HFSE-REE minerals. Moreover, the observed textural disequilibrium of newly formed minerals (pseudomorphs, patchy zoning, dissolution/reprecipitation textures) suggests the evolution of metasomatizing fluids towards more acidic conditions at lower temperatures. In summary, the selective mobilization of chemical components was related to a shift in fluid composition, $\mathrm{pH}$, and temperature. This study emphasizes the importance of relating field studies and petrographic observations to detailed mineral compositions, leading to the construction of litho-geochemical models for element mobilization in crustal magmatic-hydrothermal settings.
\end{abstract}

Keywords: metamorphic contact aureole; metasomatism; HFSE/REE-bearing minerals; HFSE/REE mobility; REE-rich metasomatic Ca-silicates 


\section{Introduction}

Understanding post-magmatic high temperature metasomatic processes of granitic bodies is essential in the investigation of the hydrothermal mobility of metals. Indeed, these processes trigger the formation of valuable metasomatic deposits of rare earth element (REE) and various other co-existing trace metals ( $\mathrm{Cu}, \mathrm{Zn}, \mathrm{Zr}, \mathrm{Ni}, \mathrm{Mo}, \mathrm{Sb}$, and $\mathrm{Tl})$ [1]. Metasomatic minerals that incorporate these elements are important geochemical indicators that can provide significant information about the nature and source of the metasomatizing fluids [2-4]. In addition to the common REE-bearing minerals, such as monazite, fluorapatite, and allanite, significant amounts of REE have been observed in several common minerals such as titanite, garnet, vesuvianite, and zircon [2-6]. The wide variety of calc-silicates formed during concurrent metasomatic events occurring at Campiglia make this magmatic-hydrothermal system a prominent case study to investigate the mobility of REE coupled with the mobility of other co-existing trace elements. Indeed, the study of micro-scale processes recorded in the chemical features of the zoned minerals can provide important insights into the compositional evolution of the metasomatizing fluids.

Tracing element mobility during metasomatism is commonly performed by comparison of the whole-rock analysis of metasomatized vs. un-metasomatized rocks in order to observe gain/loss of elements [5]. However, when element mobility is limited (ten to hundreds of meters), then comparison of whole-rock analysis alone may obscure some micro-scale processes (i.e., replacement textures and pseudomorphism). Moreover, the geochemical evolution of metasomatic fluids may be recorded in individual zones in metasomatic minerals, as observed for garnet [7,8], Ti-bearing minerals $[9,10]$, as well as high-field-strength elements (HFSE) and REE accessory minerals [11] from metasomatic environments where mineral growth reflects the combined effects of heating and fluid infiltration. Therefore, the determination of major and trace elements in selected minerals has to be integrated with geological data (field relationships, textural evidence, mineral parageneses). This analytical combination allows for better evaluation of the contribution of each mineral phase to the overall change in fluid composition as well as the identification of possible litho-geochemical vectors of the metasomatism. Moreover, performing a detailed in-situ geochemical investigation of minerals involved in a metasomatic process may have implications for the evaluation of the metasomatic mobility of the studied elements. Thus, the aim of this study is to investigate how metasomatism affects the mobilization/concentration of elements in a granite body with a peraluminous nature emplaced in a shallow crustal setting. In this work we correlate geochemical changes on the micro-scale to regional hydrothermal circulation and element mobilization. Moreover, this study attempts to determine the geochemical evolution of hydrothermal fluids during metasomatic stages, by investigating the changes in trace element composition of the main rock-forming minerals and defining key metasomatism reactions linking mineral textures and chemistry.

At Campiglia Marittima (Figure 1), previous work has ascribed mineralogical and geochemical variations in the metasomatized granite to the interaction between granitic magma and $\mathrm{CO}_{2}$-rich fluids released during decarbonation reactions in the heated marble country rock and/or auto-metasomatism caused by late-stage hydrothermal fluids emanating from the crystallizing magma [12,13]. However, the data obtained by mineralogical, textural, and geochemical investigation of the granite, endoskarn, and exoskarn bodies allow us to speculate that $\mathrm{CO}_{2}$ played an important role as a metasomatizing fluid only at the very beginning of metasomatic activity during thermal metamorphism, leading to calcite dissociation before other fluids prevailed on it. Furthermore, our companion study provides evidence for another potential contribution of elements originating from an external source [1], which is manifested by two metasomatic events-the first characterized by circulation of K-rich, then $\mathrm{Ca}(-\mathrm{Mg})$-rich fluids, and the second represented by acidic, F-rich fluids.

According to reference [1], the wide variety of calc-silicates (diopside, titanite, vesuvianite, garnet, and epidote group minerals) formed during the first metasomatic event, together with the mineral disequilibrium features developed during the second, acidic event (pseudomorphs, patchy zoning, dissolution/reprecipitation textures), make Campiglia igneous-hydrothermal complex a prominent 
case study in which to investigate the evolution of fluids and element mobility resulting from the metasomatism of a peraluminous granite. In this study, we combine (i) detailed mineralogical and textural investigations, (ii) whole-rock and mineral geochemical analysis, and (iii) in situ trace element determinations, which allow us to infer the elemental transfer mechanism during metasomatic processes.
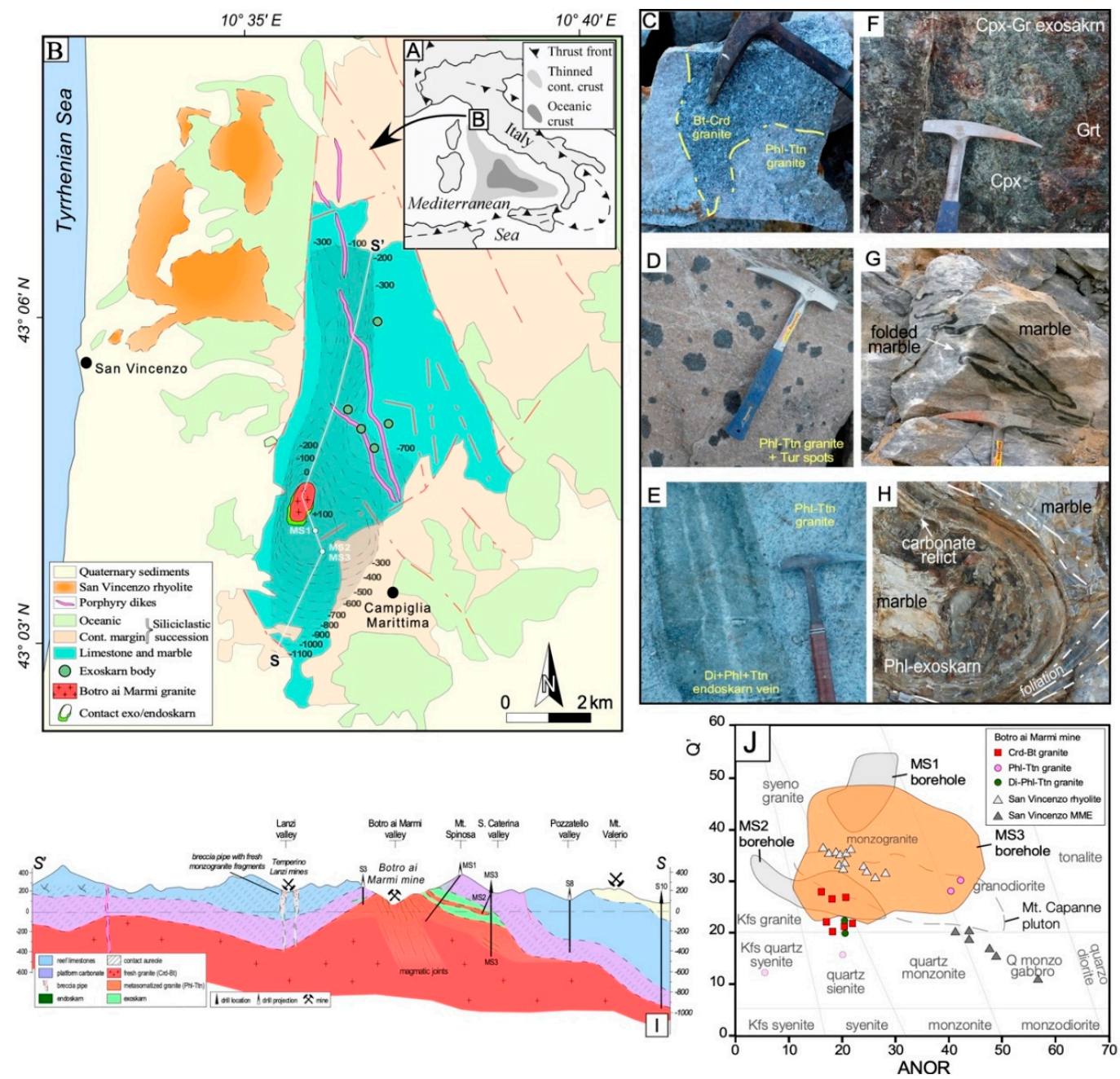

Figure 1. (A) Location map of the Campiglia area and (B) schematic geological map (after [1]). The pluton roof morphology is also reported (grey lines). (C) Cordierite-biotite (Crd-Bt) vs. phlogopite-titanite (Phl-Ttn) granite. (D) Metasomatized granite with tourmaline (Tur) orbicoles. (E) Endoskarn. (F) Vesuvianite-garnet (Cpx-Grt) exoskarn with calcite veins. (G) Centimetric folds in white-grey marble. (H) Folded marble replaced by phlogopite-diopside (Di) exoskarn, into layered grey marble. The core of the fold shows an indented contact. (I) Cross section showing lithological distribution with depth and the location of drill cores (modified after [1]). (J) $Q^{\prime}$-ANOR classification diagram for plutonic rocks [1]. Q' $=100 \times[\mathrm{Qtz} /(\mathrm{Qtz}+\mathrm{Ab}+\mathrm{O}+\mathrm{An})]$ and $\mathrm{ANOR}=100 \times[\mathrm{An} /(\mathrm{An}+\mathrm{Or})]$, where Qtz (quartz), Ab (albite), Or (ortose), and An (anorthite) are normative minerals.

\section{Geological Petrographic Background}

The Campiglia Marittima area (hereafter Campiglia) is characterized by a north to south trending horst of Mesozoic carbonate rocks, confined in a Jurassic-Eocene siliciclastic succession. The shallow crustal emplacement, at ca. 0.10-0.15 GPa [13], of the Botro ai Marmi (BM) granite pluton occurred at $\sim 5.44 \mathrm{Ma}$ (zircon ID-TIMS U-Pb age) [14,15]. The thermal aureole reached temperatures as high as $500-550{ }^{\circ} \mathrm{C}$ at the contact $[13,16]$. Later, at $4.30 \pm 0.13 \mathrm{Ma}$ (whole-rock K-Ar age) [17], mafic and felsic porphyritic bodies crosscut the contact aureole produced by the pluton in the host carbonates 
$\left(\sim 8 \mathrm{~km}^{2}\right)$ [18]. Finally, to the west of the horst, the rhyolitic extrusive complex of San Vincenzo was emplaced at $4.38 \pm 0.04 \mathrm{Ma}$ (sanidine ${ }^{40} \mathrm{Ar}^{39} \mathrm{Ar}$ age) [19]. In the Campiglia horst, it is possible to distinguish between metasomatic and ore bodies in close spatial association with the BM granite. These lithologic types occur as (i) two important granite typologies, a pristine cordierite-biotite granite, and a pinkish-white granite. The latter is characterized by an intense metasomatic replacement of biotite by phlogopite, Ti-rich minerals, and minor chlorite; (ii) an endoskarn system resulting from the metasomatism of the igneous rock, which is developed along granite joints; (iii) a variety of exoskarns resulting from the metasomatic replacement of the host carbonate (see Figure 1); (iv) the main Campiglia Fe-Cu-Zn-Pb(-Ag) skarn deposit, which consists of several bodies and veins that crop out discontinuously [18]; and (v) minor Sn-W-As bodies which outcrop nearby [18], and are not described in this work. These lithologic types originate from an igneous stage, a potassic-calcic metasomatic episode, and a lower temperature acidic metasomatic stage [1].

As reported in reference [1], the BM pluton has a syenogranitic to monzogranitic composition $\left(\mathrm{SiO}_{2}=68-72 \mathrm{wt} \%\right)$ and a peraluminous character (Figure 1) [1]. The cordierite-biotite granite is found in a few small outcrops at the BM mine. It is a medium-grained rock with K-feldspar phenocrysts (5-10 vol. \%). Its primary igneous assemblage consists of K-feldspar (30-35 vol. \%), quartz (30-35 vol. \%), plagioclase (20-30 vol. \%), and biotite (5-10 vol. \%), along with late-magmatic tourmaline and accessory cordierite, apatite, and zircon. Tabular K-feldspar (orthoclase, $\mathrm{Or}_{85-90}$ ) also occurs as megacrysts (up to ca. $5 \mathrm{~cm}$ ). Plagioclase $\left(\mathrm{An}_{35-45}\right)$ usually shows enrichment in the albitic component moving from core to rim. The rim is characterized by a clear, thin oligoclase overgrowth $\left(\mathrm{An}_{10-15}\right)[1,14,15]$. Moreover, the authors of reference [1] argued that, after emplacement and crystallization, the circulation of high-temperature metasomatic fluids triggered a pervasive potassic-calcic metasomatism of the cordierite-biotite granite (Figure 2).

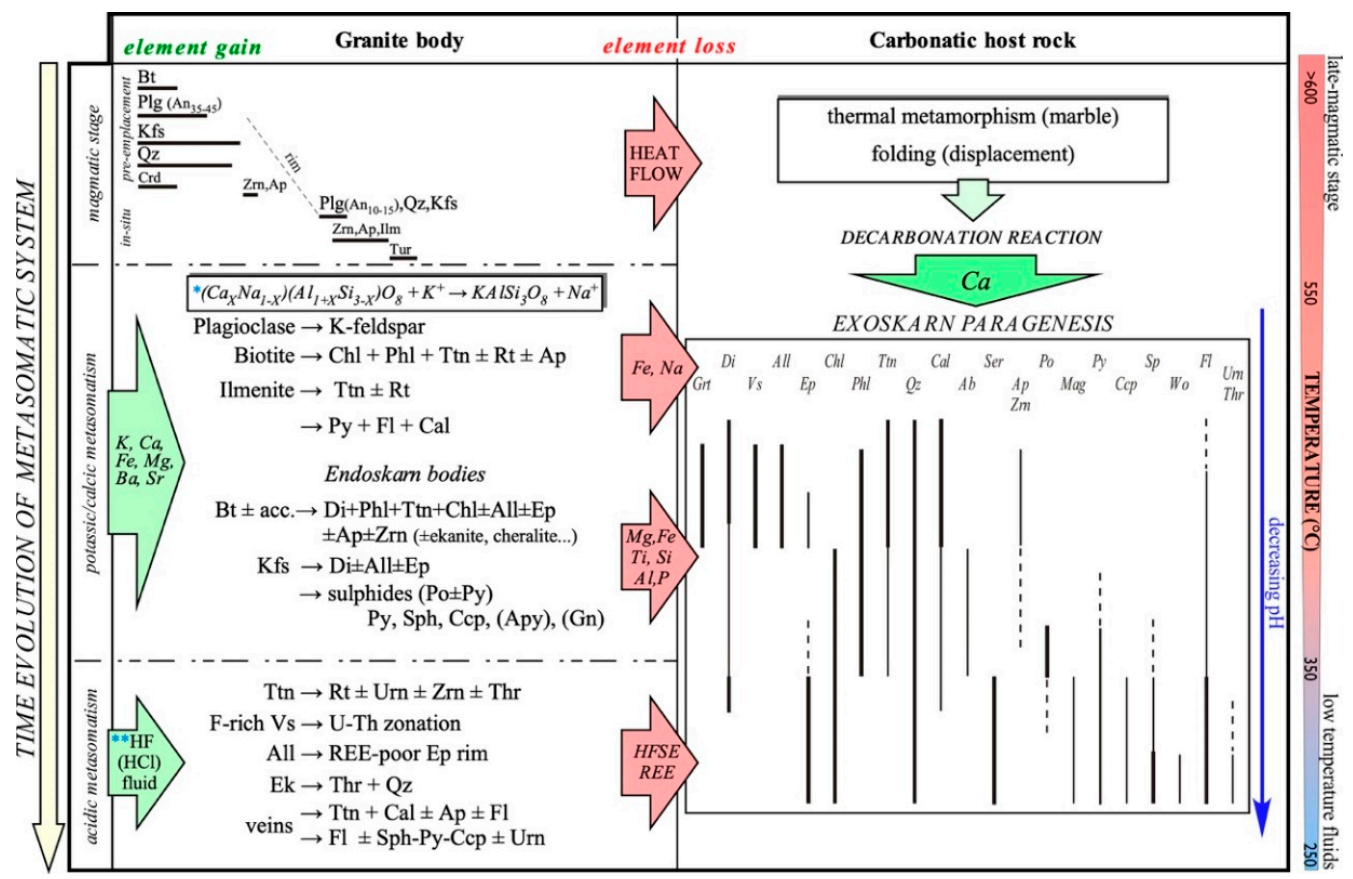

Figure 2. Mineral paragenesis for the original and metasomatic assemblages from the Campiglia system, modified after [1]. *Plagioclase (Plg) rim $\left(\mathrm{An}_{10-15}\right)$ completely replaced by K-feldspar (Kfs), while the plagioclase core $\left(\mathrm{An}_{35-45}\right)$ is partially replaced. ${ }^{* *}$ calc-silicates dissolution/replacement, HFSE and REE local mobilization, chemical zoning of vesuvianite (Vs), titanite (Ttn), diopside (Di) and garnet $(\mathrm{Grt})$. All = allanite; $\mathrm{Ap}=$ apatite; $\mathrm{Apy}=$ arsenopyrite; $\mathrm{Bt}=$ biotite; $\mathrm{Cal}=$ calcite; $\mathrm{Ccp}=$ calcopyrite; $\mathrm{Chl}=$ chlorite; $\mathrm{Crd}=$ cordierite; $\mathrm{Ep}=$ epidote; $\mathrm{Fl}=$ fluorite; $\mathrm{Gn}$ = galena; Ilm = Ilmenite; $\mathrm{Phl}$ = phlogopite; Py = pyrite; $\mathrm{Po}=$ pyrrhotite; $\mathrm{Qz}=$ quartz; Rt = rutile; $\mathrm{Sph}=$ sphalerite; Tur = tourmaline; Urn = uraninite; Zrn = zircon. Mineral abbreviations from reference [20]. 
Potassic metasomatism affected the whole granite body, leading to the almost complete replacement of the cordierite-biotite granite by phlogopite-titanite granite (Figure 1). The pinkish-white metasomatized granite ( $95 \mathrm{vol} . \%$ of the outcropping granite) is characterized by the almost complete replacement of biotite by phlogopite $\left(50 \% ; 100 \cdot \mathrm{Mg} /\left(\mathrm{Mg}+\mathrm{Fe}^{2+}\right)=\mathrm{Mg} \#=0.5\right)$, chlorite $(30 \%)$, and titanite $(20 \%)$, which has been later partially converted to rutile [1]. Biotite relics show an abundance of $\mathrm{FeO}$ (up to $25 \mathrm{wt} \%$ ) and $\mathrm{TiO}_{2}$ (up to $4 \mathrm{wt} \%$ ), common layer-by-layer replacement by chlorite and/or phlogopite, and numerous inclusions of metasomatic minerals (i.e., titanite, fluorite, rutile, and adularia). In this rock, the content of the plagioclase (oligoclase) is considerably reduced to $\sim 5$ vol. $\%$. This mineral is usually replaced by interstitial K-feldspar $\left(\mathrm{Or}_{80-90}\right)$, which shows a composition similar to orthoclase in the cordierite-biotite granite [15]. The widespread occurrence of minor diopside, amphibole, and accessory minerals (including apatite and zircon) is important evidence of metasomatic reactions. Concurrently, a calcic metasomatic event affected the original granite generating a system of endoskarn-aligned bodies along the granite joints to join the exoskarn aureole, and both the granite and the marble at the pluton-host contact, which indicate complex fluid circuits. In endoskarn bodies, where the Ca activity is prominent, biotite and feldspar are replaced by diopside and other calc-silicates (50-60 vol. \%) such as titanite (5-10 vol. \%; occasionally up to few $\mathrm{cm}$ ) and phlogopite (10-15 vol. \%). Minor epidote, albite, apatite, and zircon, together with accessory sulfides and calcite (5-10 vol. \%), occur in the incipient metasomatized granite. Instead, exoskarn bodies occur as massive bodies at the pluton-marble contact or as the replacement of the ductively folded carbonatic host-rock, suggesting preferential pathways for metasomatic fluids (Figure 1) [1,18]. The most representative metasomatic minerals are calc-silicates (i.e., diopside, vesuvianite, garnet, titanite, and allanite; up to 60 vol. \%), calcite (up to 30 vol. \%), as well as phlogopite, minor scapolite, and sulfides. Multiple effects from hydrothermal fluid circulation overlap through time, resulting in complex mineral associations, such as replacement textures (allanite, REE-bearing minerals, and pyroxenoids replacing garnet, pyroxene, titanite), pseudomorphism, and strong mineral zoning [1].

The ubiquitous presence of fluorite in skarn, granite, and quartz-fluorite veins suggests that acidic F-rich fluids circulated in the system during the whole of the metasomatic activity [15]. The continuous crystallization of calc-silicates (Ca-sequestration) and the increased F activity led to the metasomatism of earlier calc-silicates. The results from this acidic metasomatic stage are highlighted by diffuse patchy zoning (i.e., titanite), dissolution-recrystallization textures, pseudomorphs, and pronounced zoning (Figure 3) [1]. Moreover, acidic metasomatism is reputed to be responsible for the intense metasomatism of accessory minerals included in biotite (apatite, zircon, monazite, and ilmenite), as suggested by aggregates of euhedral accessory minerals (apatite, zircon, and monazite) bordering deeply metasomatized biotite grains (Figure 3I-L). In addition, the crystallization of Ca-REE-rich minerals, such as allanite and cheralite, during this stage reflect the mobilization of HFSE/REE by fluids with increasing acidity (Figure 3F) [1,14,15]. 

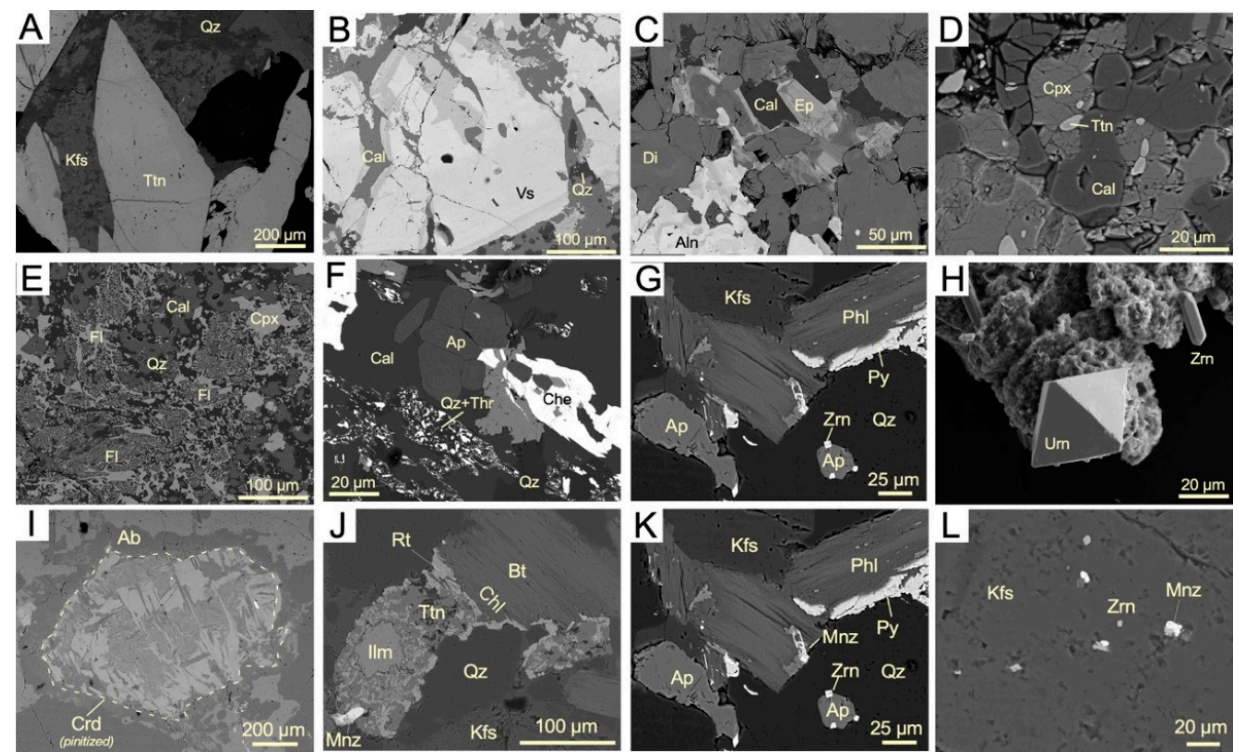

Figure 3. Backscattered electron images showing (A) Euhedral zoned titanite (Ttn) with relict K-feldspar (Kfs) and quartz (Qz), in the endoskarn. (B) Zoned vesuvianite (Vs) with fractures filled by REE-enriched overgrowth. (C) Late allanite (Aln) replacing epidote (Ep) in diopside-rich exoskarn. (D) Dissolution texture of diopside (Di) and titanite, with late calcite (Cal). (E) Fluorite (Fl) + calcite + quartz + diopside pseudomorphs in a clinopyroxene-rich exoskarn. (F) Pseudomorph of (Thr)thorite + quartz after cheralite (Che), with apatite (Ap), quartz and calcite in (Cpx)clinopyroxene-rich exoskarn. (G) Metasomatic fluorapatite and zircon (Zrn) bordering metasomatized biotite (Bt) partially replaced by phlogopite (Phl) (H) Zircon and uraninite (Urn) on "spongy" titanite. (I) Pinitized cordierite (Crd) with albite $(\mathrm{Ab})$ corona, in monzogranite. (J) Ilmenite (Ilm) replaced by titanite and rutile (Rt) related to biotite replaced by chlorite (Chl). (K) Apatite, zircon, pyrite (Py) and monazite (Mnz) in altered granite. (L) Metasomatic monazite and zircon in secondary K-feldspar. Mineral abbreviations from reference [20].

\section{Methods}

Major elements of selected minerals were analyzed using a JEOL 8200 electron microprobe equipped with five wavelength dispersive spectrometers (WDS) and a PulseTor Maxim EDS detector, at the University of Milano, Milano, Italy. The WDS analysis were conducted at $15 \mathrm{kV}$, with a $30 \mathrm{nA}$ beam current and a beam diameter of $5 \mu \mathrm{m}$. The smallest crystals were only identified from element maps and semi-quantitative analysis using a Philips XL30 scanning electron microscope equipped with an EDAX DX4 detector and a field emission-SEM (FE-SEM; University of Pisa, Pisa, Italy). Additionally, a Thermo Scientific iCAP-Q ICP-QMS, coupled with a Photon Machine G2 193 nm excimer Laser Ablation system, was used for high spatial resolution trace element determination of the same minerals at the University of Perugia, Perugia, Italy. ${ }^{42} \mathrm{Ca},{ }^{29} \mathrm{Si}$, and ${ }^{47} \mathrm{Ti}$, previously determined by electron microprobe analysis, were used as internal standards [21]. Detailed analytical methods are reported in Supplementary File S1.

\section{Results-Microtextures and Mineral Chemistry}

Textural evidence from field relations and thin sections, along with scanning electron microscopy coupled with energy dispersive spectroscopy (SEM-EDS) analyses, have been used as the basis to select the minerals involved in the metasomatic reactions (Figure 3, Table 1) [1], and to perform major and trace element analysis. The mineral chemistry has been used to document the mobility of elements between the granite, the marble, and metasomatic products. According to reference [1], variations in the mineral chemistry from the feldspars, micas, calc-silicates, Ti-bearing minerals, and accessory minerals indicate multiple processes of mineral-fluid interaction and reflect the metasomatic fluid evolution. 
Table 1. Main metasomatic minerals observed in the Campiglia system.

\begin{tabular}{|c|c|c|c|c|c|c|c|c|c|c|}
\hline \multirow{2}{*}{ Origin } & \multirow{2}{*}{\multicolumn{2}{|c|}{ General Group }} & \multirow{2}{*}{$\begin{array}{c}\text { Min. } \\
\text { Name }\end{array}$} & \multirow{2}{*}{$\begin{array}{c}\text { Mineral Chemistry } \\
\text { Main Features }\end{array}$} & \multicolumn{6}{|c|}{ Abundance (vol. \%) } \\
\hline & & & & & $\begin{array}{l}\text { Crd-Bt } \\
\text { Granite }\end{array}$ & $\begin{array}{l}\text { Phl-Ttn } \\
\text { Granite }\end{array}$ & Endoskarn & $\begin{array}{c}\text { Di- } \\
\text { Exoskarn }\end{array}$ & $\begin{array}{c}\text { Phl- } \\
\text { Exoskarn }\end{array}$ & $\begin{array}{c}\text { Grt-Vs } \\
\text { Exoskarn }\end{array}$ \\
\hline \multirow{9}{*}{ Magmatic } & Quartz & Quartz & $\mathrm{Qz}$ & & $30-35$ & $40-45$ & $5-10$ & $* * *$ & & $* *$ \\
\hline & Feldspar gr. & Plagioclase & $\mathrm{Ab}$ & & $5-10$ & $* * *$ & $* * *$ & $* * *$ & $* * *$ & \\
\hline & & & An & & $15-20$ & $5-10$ & $5-10$ & $* * *$ & $* *$ & $* *$ \\
\hline & & K-feldspar & Kfs & & $30-35$ & $20-25$ & $* * *$ & $* * *$ & $* * *$ & $* *$ \\
\hline & Phyllosilicate & Micas & $\mathrm{Bi}$ & $\mathrm{TiO}_{2}>3$ wt $\%, \mathrm{Fe}>\mathrm{Mg}$ & $5-10$ & $* *$ & $* *$ & & & \\
\hline & HFSE-REE min. & Phosphates & Ap & & $*$ & * & * & & & \\
\hline & & & Mnz & & * & * & * & & & \\
\hline & & Zircon & Zrn & & $*$ & $*$ & * & & & \\
\hline & Tourmaline & Tourmaline & Tur & & $* * *$ & $* * *$ & & & & \\
\hline \multirow{16}{*}{ Matasomatic } & Quartz & Quartz & $\mathrm{Qz}$ & & & $* * *$ & $* * *$ & $* * *$ & & $* * *$ \\
\hline & Feldspar gr. & Plagioclase & $\mathrm{Ab}$ & & & & $* * *$ & $* * *$ & & \\
\hline & & K-feldspar & Kfs & & & $5-10$ & $* * *$ & $* * *$ & & $* * *$ \\
\hline & Phyllosilicate & Micas & $\mathrm{Bi}$ & $\begin{array}{c}\text { High } \mathrm{TiO}_{2}>3 \text { wt } \% \\
\mathrm{Fe}>\mathrm{Mg}\end{array}$ & & & ** & & & \\
\hline & & Phlogopite & Phl & $\begin{array}{c}\mathrm{Mg}>>\mathrm{Fe}, \\
<<\mathrm{F}, \mathrm{Nb}, \mathrm{Nd}, \mathrm{LREE}\end{array}$ & & $5-10$ & $5-10$ & $5-10$ & $30-35$ & $5-10$ \\
\hline & & Chlorite & Chl & $\mathrm{Mg}>>\mathrm{Fe}, \mathrm{K}$, trace $\mathrm{F}$ & & $* * *$ & $* * *$ & $* * *$ & $* * *$ & $* * *$ \\
\hline & Ti-minerals & Ti-minerals & Ttn & high Al, HFSE, LREE, F & & $* * *$ & $5-10$ & $5-10$ & $5-10$ & $5-10$ \\
\hline & & & Rt & $\mathrm{Nb}, \mathrm{Cr}, \mathrm{V}, \mathrm{Al}, \mathrm{Zr}, \mathrm{Sc}, \mathrm{Sn}$ & & $*$ & $*$ & $*$ & $*$ & $*$ \\
\hline & Calc-silicates & Pyroxene & $\mathrm{Di}$ & $\mathrm{Zn}, \mathrm{Na}$ & & $* *$ & $15-25$ & $15-25$ & $25-35$ & $5-10$ \\
\hline & & & $\mathrm{Hd}$ & $\mathrm{Zn}, \mathrm{Na}$ & & & $* * *$ & & & \\
\hline & & Vesuvianite & Vs & $\begin{array}{c}\text { Th, U, LREE, F, Li, } \\
\text { Be, Zn, Zr }\end{array}$ & & & $* *$ & $* * *$ & $* * *$ & $20-40$ \\
\hline & & Garnet & Gr & & & & $* *$ & $* * *$ & $* * *$ & 11232 \\
\hline & & & Ad & & & & & $* *$ & $* *$ & $* * *$ \\
\hline & & Epidote gr. & Ep & $\mathrm{Sr}, \mathrm{Sn}, \mathrm{Sb}, \mathrm{Th}, \mathrm{U}$ & & * & $* * *$ & $* * *$ & $* * *$ & $* * *$ \\
\hline & & & All & $\mathrm{Sr}, \mathrm{Sn}, \mathrm{Sb}, \mathrm{Th}, \mathrm{U}$ & & $*$ & $* * *$ & $* * *$ & $* * *$ & $* * *$ \\
\hline & & Calcite & Cal & & & $* *$ & $5-10$ & $5-10$ & $15-20$ & $* * *$ \\
\hline
\end{tabular}


Table 1. Cont.

\begin{tabular}{|c|c|c|c|c|c|c|c|c|c|c|}
\hline \multirow{2}{*}{ Origin } & \multirow{2}{*}{\multicolumn{2}{|c|}{ General Group }} & \multirow{2}{*}{$\begin{array}{c}\text { Min. } \\
\text { Name }\end{array}$} & \multirow{2}{*}{$\begin{array}{c}\text { Mineral Chemistry } \\
\text { Main Features }\end{array}$} & \multicolumn{6}{|c|}{ Abundance (vol. \%) } \\
\hline & & & & & $\begin{array}{l}\text { Crd-Bt } \\
\text { Granite }\end{array}$ & $\begin{array}{l}\text { Phl-Ttn } \\
\text { Granite }\end{array}$ & Endoskarn & $\begin{array}{c}\text { Di- } \\
\text { Exoskarn }\end{array}$ & $\begin{array}{c}\text { Phl- } \\
\text { Exoskarn }\end{array}$ & $\begin{array}{c}\text { Grt-Vs } \\
\text { Exoskarn }\end{array}$ \\
\hline \multirow{12}{*}{ Matasomatic } & HFSE-REE min. & Phosphates & Ap & $\mathrm{F}$ & & * & * & $* *$ & $* *$ & * \\
\hline & & & Mnz & & & * & * & & & \\
\hline & & & Che & & & * & * & & & \\
\hline & & Zircon & Zrn & & * & * & * & * & * & * \\
\hline & & Th-U min. & Urn & Th & * & * & * & * & * & * \\
\hline & & & Thr & $\mathrm{U}$ & * & * & * & * & * & * \\
\hline & & Fluorite & $\mathrm{Fl}$ & Sr, Y, LREE & $* *$ & $* *$ & $* *$ & ** & $* *$ & $* *$ \\
\hline & & Sulfides & Py & & $* * *$ & $* * *$ & $* * *$ & $* * *$ & $* * *$ & $* * *$ \\
\hline & & & Po & & $* *$ & $* * *$ & $* * *$ & $* *$ & $* *$ & $* * *$ \\
\hline & & & $\mathrm{Sp}$ & & $* *$ & $* *$ & $* *$ & $* *$ & $* *$ & $* *$ \\
\hline & & & Ccp & & $* *$ & $* *$ & $* *$ & $* *$ & $* *$ & $* *$ \\
\hline & & & Gn & & $* *$ & $* *$ & $* *$ & $* *$ & $* *$ & $* *$ \\
\hline
\end{tabular}

Note: $^{*}=$ accessory; ${ }^{* *}=1$ vol. \%; *** = 1-5 vol. \%. Ab = albite; $\mathrm{An}=$ anorthite; $\mathrm{Bi}=$ biotite; $\mathrm{Ap}=$ apatite; Mnz = monazite; Ttn = titanite; Rt = rutile; $\mathrm{Di}=$ diopside; Hd = hedenbergite; $\mathrm{Gr}=$ grossular; $\mathrm{Ad}=$ andradite; $\mathrm{All}=$ allanite; $\mathrm{Che}=$ cheralite; $\mathrm{Urn}=$ uraninite; $\mathrm{Thr}=$ thorite; $\mathrm{Py}=$ pyrite; $\mathrm{Po}=$ pyrrhotite; $\mathrm{Sp}=\mathrm{sphalerite}$; $\mathrm{Ccp}=$ chalcopyrite; $\mathrm{Gn}=$ galena. $\mathrm{Mineral}$ abbreviations from reference [20]. 


\subsection{Magmatic Minerals}

Cordierite-biotite granite is found as a few small patches inside the BM mine (Figure 1) in deep portions of monzogranite brought at shallow depth by breccia pipes and, moving to the south, at increasing depth in several boreholes [1]. The original pluton is a medium-grained cordierite-biotite granite. The primary igneous assemblage consists of K-feldspar (30-35 vol. \%), quartz (30-35 vol. \%), plagioclase (20-30 vol. \%), and biotite (5-10 vol. \%), along with accessory cordierite, fluorapatite, zircon, and late-magmatic tourmaline (Figure 2) [1].

\subsubsection{Feldspar Group}

The alkali feldspar is the main mineral in the granite (50-30 vol. \%) and is found as two generations of crystals-igneous and metasomatic (Figure 4). The first igneous generation usually occurs as medium-sized euhedral crystals, occasionally forming tabular phenocrysts up to $3-5 \mathrm{~cm}$ in size, and as late magmatic interstitial grains. There is no significant chemical variability between crystal core and rim (orthoclase, $\mathrm{Or}_{85-90}$ ). Plagioclase crystals (up to 30 vol. \%) are subhedral to euhedral, showing a compositional zoning from $\mathrm{An}_{35-45}$ to $\mathrm{An}_{10-15}$ (Table 2).

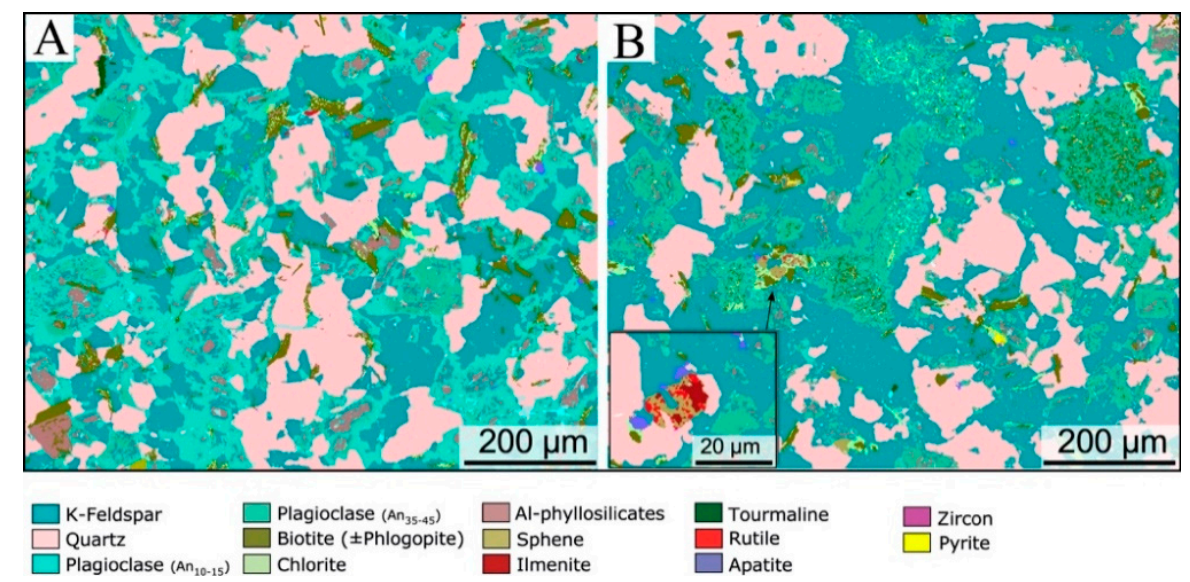

Figure 4. Quantitative Evaluation of Minerals by Scanning Electron Microscopy (QEMSCAN) images of two granite samples. (A) Thick overgrowth of oligoclase $\left(\mathrm{An}_{10-15}\right)$ on andesine plagioclase $\left(\mathrm{An}_{35-45}\right)$. (B) K-feldspar replace albite and increases from 30 vol. \% to about 50 vol. \%.

Table 2. Selected scanning electron microscopy coupled with energy dispersive spectroscopy (SEM-EDS) and electron microprobe analyses for minerals from the Botro ai Marmi (BM) granite.

\begin{tabular}{ccccccccccccc}
\hline $\begin{array}{c}\text { Rock } \\
\text { Type }\end{array}$ & \multicolumn{2}{c}{$\begin{array}{c}\text { Bt-Crd } \\
\text { Granite }\end{array}$} & \multicolumn{2}{c}{$\begin{array}{c}\text { Phl-Ttn } \\
\text { Granite }\end{array}$} & \multicolumn{3}{c}{ Bt-Crd Granite } & \multicolumn{2}{c}{$\begin{array}{c}\text { Bt-Crd } \\
\text { Granite }\end{array}$} & \multicolumn{2}{c}{ Phl-Ttn Granite } \\
\hline Mineral & Kfs1 & Kfs2 & Kfs4 & Kfs5 & Plg-5r & Plg-5m & Plg-5c & Bt (BM5) & Phl (GBM2A) \\
\hline $\mathrm{SiO}_{2}$ & 65.7 & 65.7 & 65.9 & 65.4 & 67.3 & 60.4 & 57.7 & 38.3 & 38.2 & 51.4 & 40.3 & 41.8 \\
$\mathrm{TiO}_{2}$ & bdl & bdl & 0.02 & 0.01 & bdl & 0.02 & bdl & 3.70 & 3.59 & 1.52 & 0.58 & 2.08 \\
$\mathrm{Al}_{2} \mathrm{O}_{3}$ & 19.5 & 19.2 & 19.6 & 19.5 & 21.5 & 26.0 & 27.8 & 15.5 & 15.6 & 6.27 & 14.5 & 13.3 \\
$\mathrm{Cr}_{2} \mathrm{O}_{3}$ & 0.02 & bdl & bdl & 0.03 & bdl & bdl & bdl & bdl & bdl & bdl & 0.02 & 0.02 \\
$\mathrm{FeO}$ & bdl & bdl & 0.03 & bdl & 0.02 & bdl & 0.20 & 17.8 & 17.2 & 1.29 & 4.94 & 6.24 \\
$\mathrm{Mno}$ & bdl & 0.01 & bdl & bdl & bdl & 0.01 & 0.02 & 0.28 & 0.27 & bdl & 0.04 & 0.04 \\
$\mathrm{MgO}$ & 0.02 & 0.02 & bdl & 0.03 & bdl & bdl & 0.01 & 9.57 & 8.92 & 23.8 & 22.1 & 20.7 \\
$\mathrm{CaO}$ & 0.08 & 0.03 & 0.10 & 0.08 & 2.96 & 6.90 & 8.70 & 0.11 & 0.05 & 0.01 & bdl & 0.03 \\
$\mathrm{Na} 2$ & 1.92 & 1.70 & 1.99 & 1.63 & 8.80 & 7.20 & 6.00 & 0.06 & 0.21 & 0.10 & 0.23 & 0.07 \\
$\mathrm{~K}_{2} \mathrm{O}$ & 14.2 & 15.0 & 13.8 & 14.7 & 0.23 & 0.16 & 0.18 & 8.47 & 8.41 & 9.96 & 10.4 & 10.2 \\
$\mathrm{~F}$ & nd & nd & nd & nd & nd & nd & nd & 0.37 & 0.41 & 3.05 & 1.37 & 2.31 \\
$\mathrm{Mg} \#$ & nd & nd & nd & nd & nd & nd & nd & 0.49 & 0.48 & 0.97 & 0.89 & 0.86 \\
$\mathrm{Fe} \#$ & nd & nd & nd & nd & nd & nd & nd & 0.51 & 0.52 & 0.03 & 0.11 & 0.14 \\
$\mathrm{Total}$ & 101.4 & 101.7 & 101.4 & 101.4 & 100.8 & 100.7 & 100.6 & 94.2 & 92.9 & 97.4 & 94.5 & 96.8 \\
\hline \multicolumn{4}{c}{}
\end{tabular}

Note: bdl = below $0.01 \mathrm{wt} \%$; $\mathrm{nd}=$ not detected; $\mathrm{Mg} \#=\mathrm{Mg} /(\mathrm{Mg}+\mathrm{Fe}) \cdot 100 ; \mathrm{Fe} \#=\mathrm{Fe} /(\mathrm{Fe}+\mathrm{Mg}) \cdot 100$. 


\subsubsection{Phyllosilicates Group}

Biotite is the only mafic mineral (together with minor late-magmatic tourmaline) observed in the granite (Figure 4). Its composition varies between annite/siderophyllite, with a Fe\# values between 0.4-0.6, comparable with other peraluminous magmas from Tuscany (Figure 5). Data plotted on a $\mathrm{MgO}-\mathrm{Al}_{2} \mathrm{O}_{3}$ discrimination diagram [22] show a biotite composition typical of peraluminous granites, according to both petrographic evidence (cordierite occurrence) and the alumina saturation index of the rock (ASI $=1.1-1.3$ ). Moreover, biotite shows a high $\mathrm{TiO}_{2}$ content (Table 2). The F content is extremely variable, ranging from $0.5 \mathrm{wt} \%$ in primary biotite up to $3 \mathrm{wt} \%$ in secondary phlogopite. The overall $\mathrm{F}$ value defines two trends that are well correlated with the Ti and Fe\# content (Figure 6).

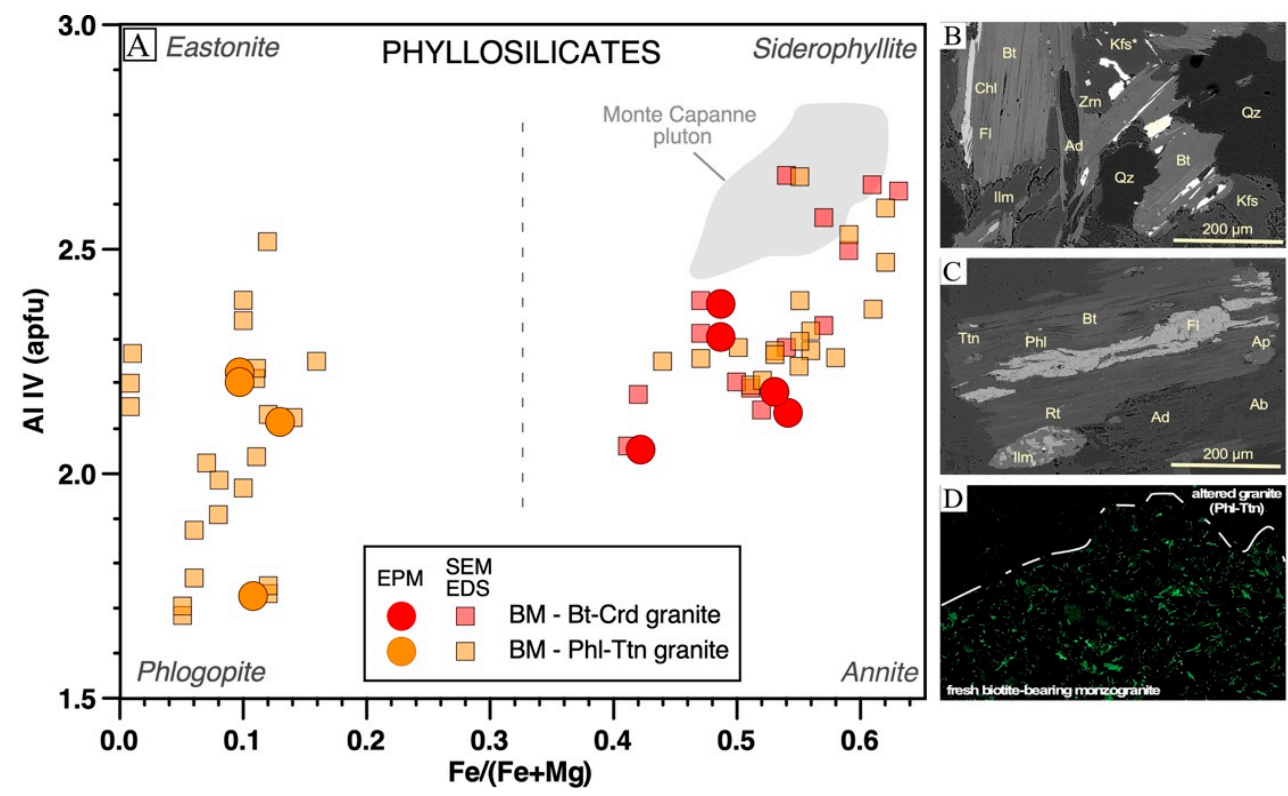

Figure 5. (A) Classification diagram of the phyllosilicates [23] from the BM granite (circle = electron microprobe (EPM) analysis; square = SEM-EDS analysis). For comparison are shown a series of phyllosilicate data from the Monte Capanne pluton [24]; a.p.f.u. = atomic unit per formula. (B,C) Backscattered electron images of biotite with fluorite (Fl) and adularia (Ad) lamellae as well as $\mathrm{k}$-feldspar (Kfs) and quartz (Qz). Biotite is replaced by chlorite (Chl), phlogopite (Phl), and titanite (Ttn). In C ilmenite (Ilm) is replaced by titanite and rutile (Rt). Apatite (Ap) and zircons (Zrn) occur both in biotite and along its border. (D) QEMSCAN Fe distribution element map at the contact between metasomatized and cordierite-biotite granite. Mineral abbreviations from reference [20].
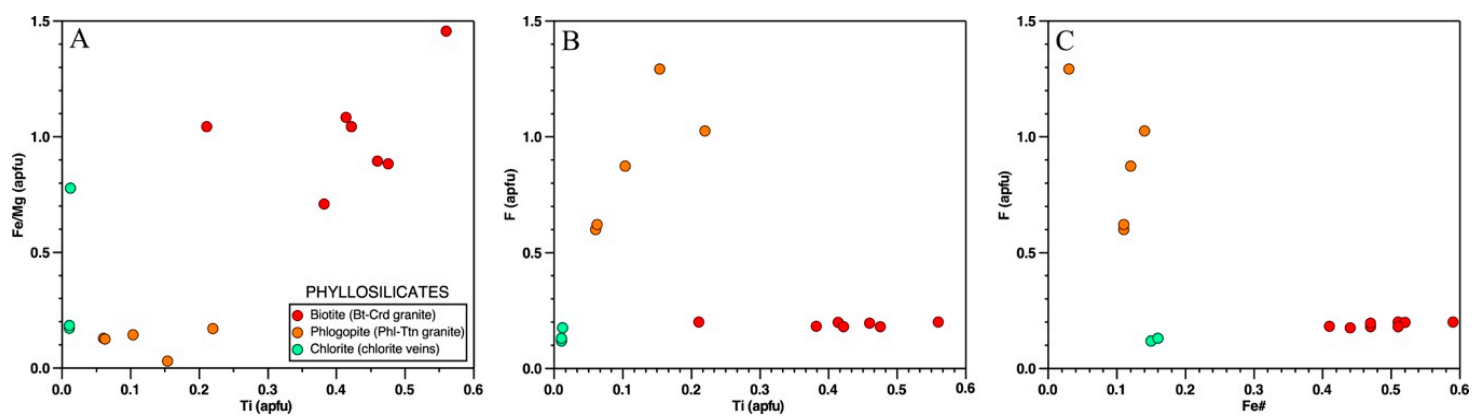

Figure 6. (A-C) Compositional diagrams for selected elements in biotite from a cordierite-biotite granite, phlogopite from a phlogopite-titanite granite, and chlorite from endoskarn bodies. 


\subsubsection{Accessory Minerals}

Cordierite represents the most abundant accessory mineral (Figure 3I), indicating the peraluminous character of the rock, typical of crustal magmatic products from Tuscany (i.e., San Vincenzo and Roccastrada rhyolite, Giglio granite). Cordierite is deeply metasomatized and replaced by pinite and thick coronas of albite, supporting alkali metasomatism. Ilmenite is commonly included in biotite, with crystals up to $100 \mathrm{~s} \mu \mathrm{m}$ in size (Figure 3J). Monazite is uncommon in biotite, except for few small euhedral crystals $(<15 \mu \mathrm{m})$ showing pseudomorphic textures, while it is commonly found as $<20 \mu \mathrm{m}$ crystals in interstitial K-feldspar and quartz or forming trails of crystals in interstitial K-feldspar (Figure $3 \mathrm{~L} ;<15 \mu \mathrm{m}$ monazite-zircon aggregates). Zircon crystals vary in size from 50 to $250 \mu \mathrm{m}$ and show variable euhedral shapes. The largest crystals are usually included in biotite, while smallest crystals are observed in interstitial K-feldspar (Figure 3K,L). Fluorapatite crystals vary in size from small euhedral crystals $(50 \mu \mathrm{m})$, usually forming an aggregate with other accessory minerals, up to $500 \mu \mathrm{m}$; it is occasionally included in fresh biotite, while commonly forming aggregates in close contact with deeply metasomatized biotite (Figure 3K).

\subsection{Metasomatic Minerals}

Metasomatic minerals from Campiglia display simple to complex zoning characterized by major and trace element variabilities [1]. Minerals, characterized by irregular zoning, increase close to the granite-host rock transition. They reflect multiple metasomatic events characterized by the increasing activity of metasomatic fluids. Pyroxene, titanite, and epidotes crystals from the exoskarn bodies show the most complex textures [1].

\subsubsection{Feldspar Group}

The metasomatic generation of feldspar is mostly found as oligoclase pseudomorphic replacement rims on igneous plagioclase (first generation) as well as along polysynthetic twinning and along fractures. The amount of replacement can be used as a rough marker for progressing metasomatism. The two generations of K-feldspar both have an $\mathrm{Or}_{85-90}$ composition. Sericitization increases toward the center of the plagioclase grains and is widespread mostly in the metasomatized granite (Figure 4; Table 2).

\subsubsection{Phyllosilicates Group}

The subdivision of the phyllosilicates into separate groups based on their chemistry is consistent with petrographic observations of fine intergrowths of either Mg-phyllosilicates and Fe-phyllosilicates, as well as hydrothermal chlorite (Figures 5 and 6; Table 1) [1]. Magmatic biotite is completely replaced by phlogopite $(\mathrm{Mg \#}=0.85-0.95)$ and chlorite, as well as new crystals of Al-rich titanite and rutile. The original granite shows an abundance of biotite (siderophyllite-annite series), while biotite from the metasomatized granite is an Mg-rich phlogopite (Figure 5). Phlogopite is slightly enriched in LREE-Nb, and quite enriched in $\mathrm{F}$ ( $3 \mathrm{wt} \%$ vs. $0.5 \mathrm{wt} \%$ in biotite). Chlorite, which commonly replaces biotite in the metasomatized granite, shows $\mathrm{F}$ contents up to $0.25 \mathrm{wt} \%$, and is observed in close spatial relation with fluorite lining the cleavage. Figure 6 shows the compositional diagram for selected elements from biotite and shows that the decrease of the $\mathrm{Fe} / \mathrm{Mg}$ ratio is positively related to $\mathrm{Ti}$, allowing for the distinction between phlogopite and the other micas. Figure 7 presents the chondrite-normalized REE pattern for bulk analysis of biotite and phlogopite, collected from the granite and exoskarn, which reflects that of the host rock. Biotite and phlogopite from the original and metasomatized granite, respectively, show a slight enrichment in LREE and depletion in HREE. In contrast, phlogopite collected from exoskarn bodies shows a less fractionated pattern, which is compatible with the whole-rock diopside-phlogopite-exoskarn pattern (see discussion). 


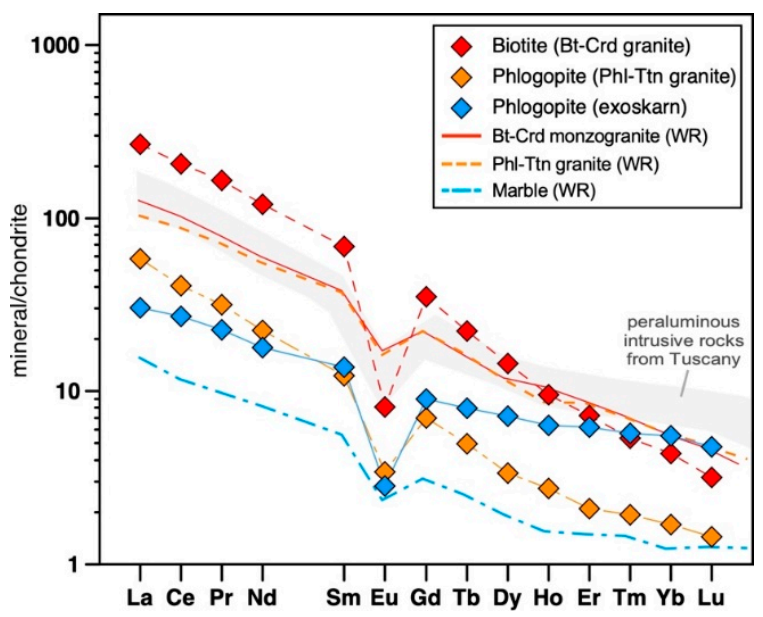

Figure 7. Chondrite-normalized REE pattern for biotite and phlogopite from the BM granite, and phlogopite from the exoskarn (bulk minerals separate). Whole-rock (WR) data from reference [1]. Chondrite normalization values after [25].

\subsubsection{Titanium Minerals}

Metasomatic titanite and rutile are widespread in samples from the BM mine and they are usually observed replacing ilmenite and/or new crystals related to metasomatized biotite. Ilmenite is partially to completely replaced by titanite, which is metasomatized to rutile during a later stage. Titanite is also observed in endoskarn veins, forming euhedral, centimetric, patchy zoned crystals [1].

Titanite occurs as euhedral to subhedral crystals and is crystallized in multiple generations (Figure 3). Electron microscope observations show variable textures, which include (i) simple zoning, (ii) patchy zoning, (iii) rim dissolution/corrosion (spongy texture), and (iv) sharp boundaries against adjacent zones (Figure 3) [1].

Figure 8 indicates that, chemically, some characteristics are common for titanite from all the lithologies, such as $\mathrm{Al}, \mathrm{Zr}, \mathrm{Th}, \mathrm{U}$, and $\mathrm{REE}$ enrichment (Table 3). The textural variability of titanite from the different environments, on the other hand, corresponds to compositional zoning. Titanite crystals show variable amount of $\mathrm{Sr}, \mathrm{Ba}, \mathrm{Cr}, \mathrm{Mn}, \mathrm{Fe}$, and $\mathrm{F}$ (Table 3, Supplementary Table S1), indicating that many elements were mobile during its growth. The average composition of titanite crystals from different environments is particularly high in $\mathrm{Al}_{2} \mathrm{O}_{3}$ content, ranging from a mean value of $3.5 \mathrm{wt} \%$ up to of $5.5 \mathrm{wt} \%$ (titanite in veins). Variations in the $\mathrm{Al}$ content partially correspond to mineral zoning (Figure 8B). Aluminum shows a positive correlation with F (0.25-0.79 wt \%) and Ti. Moreover, a negative correlation exists between $\mathrm{Ti}$ and $\mathrm{F}$ and $\mathrm{Al}+\mathrm{Fe}$ vs. F. Calcium shows a negative correlation with REE and $\mathrm{Zr}$ (not show here). Elements on the $\mathrm{M}^{3+}$ site define a negative trend with the $\mathrm{Ca}+\mathrm{Ti}$ content. Thorium (20-500 ppm) shows a positive correlation with $\mathrm{U}(20-700 \mathrm{ppm})$, reaching maximum values in the centimetric, patchy zoned titanite from the metasomatic veins. REE concentrations in titanite show a negative correlation with $\mathrm{U} / \mathrm{Th}$ ratio (Figure $8 \mathrm{D}-\mathrm{G}$ ) from core to rim. 

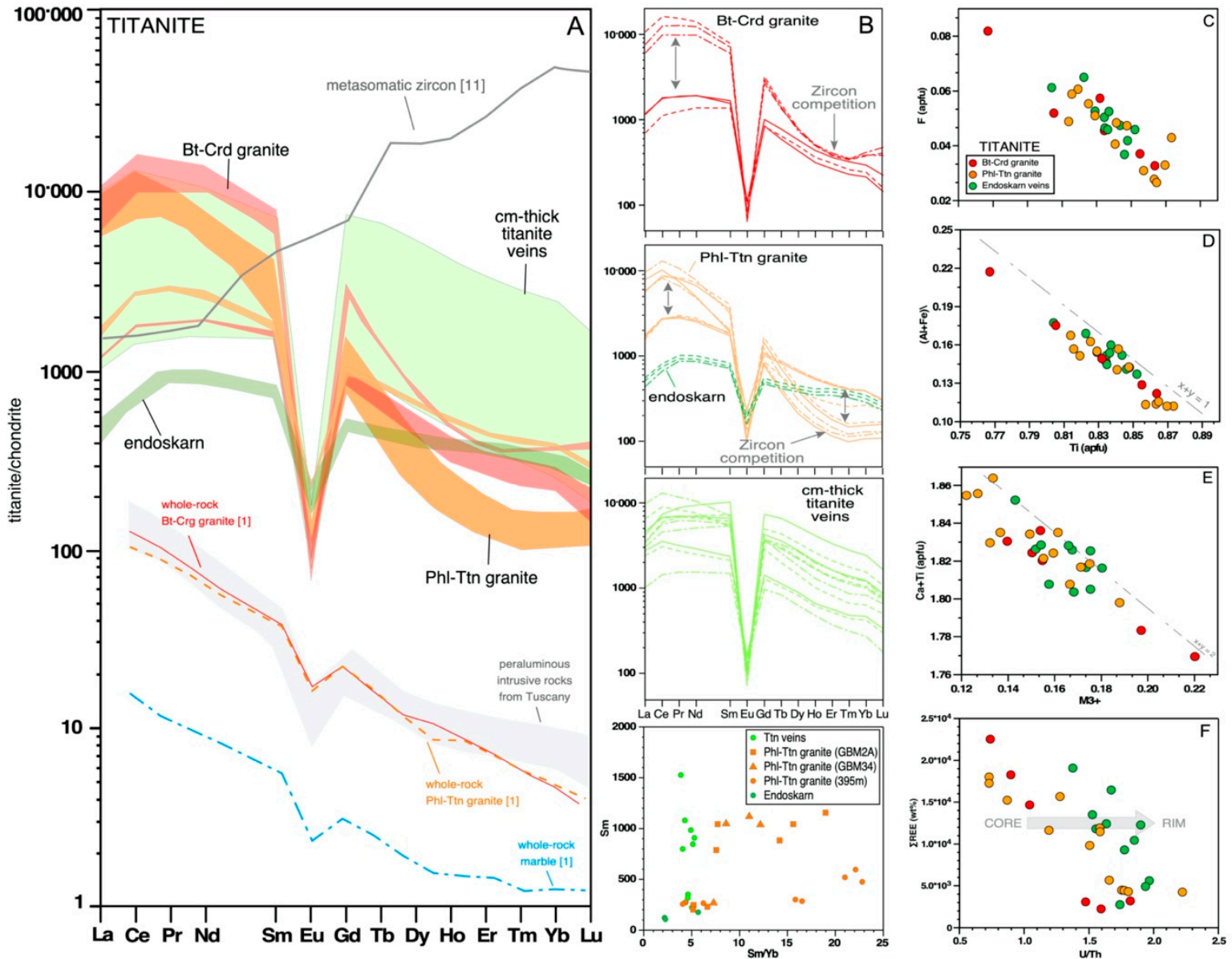

Figure 8. (A) Chondrite-normalized REE patterns for titanite from the biotite granite, the phlogopitetitanite granite and the endoskarn. On the right (B) detailed chondrite-normalized REE patterns for titanite from each lithology are reported. (C-F) Compositional diagrams of metasomatic titanite from various lithologic types. For comparison, whole-rock (WR) data are taken from reference [1]. Chondrite normalization values are taken from reference [25].

The maximum REE content occurs in titanite from the cordierite-biotite granite (Table 3). Other important enriched elements are Zr (200-6000 ppm), Nb (180-2500 ppm), Y (up to 5370 ppm), and Ta (up to $250 \mathrm{ppm}$ ). Niobium and Ta show a perfect positive correlation (Figure 9). Furthermore, back-scattered electron images of titanite from the granite show homogeneous crystals or simple zoning with distinct dark and bright overgrowths. On the other hand, titanite grains from endoskarn and exoskarn show more complex patterns, with older zones that truncate and embay younger ones. Each zone appears to be internally homogeneous with sharp boundaries against adjacent zones. Even if titanite crystals from granite, endoskarn, and veins do not show significant internal variation in the REE-pattern during growth, some clear evidences do exist (Figure 8A,C). All the REE-patterns highlight La-Ce depletion. Titanite from both slightly altered biotite-cordierite and phlogopite-titanite granite shows two different REE patterns. The first is characterized by a granite-like pattern, while the second shows an overall higher REE content and strong depletion in HREE. Euhedral titanite crystals from veins and endoskarn bodies show granite-like patterns, which are characterized by a moderately fractionated profile with an Eu negative anomaly $\left(\mathrm{Eu} / \mathrm{Eu}^{*}=\right.$ measured $\left.\mathrm{Eu} / \mathrm{chondritic} \mathrm{Eu}\right)$. 
Table 3. Selected electron microprobe and laser ablation inductively coupled plasma mass spectrometry (LA-ICP-MS) analyses for titanite crystals from the BM mine.

\begin{tabular}{|c|c|c|c|c|c|c|c|c|c|c|}
\hline \multirow{2}{*}{$\begin{array}{c}\text { Rock Type } \\
\text { Mineral }\end{array}$} & \multicolumn{3}{|c|}{ Bt-Crd Granite } & \multicolumn{2}{|c|}{ Phl-Ttn Granite } & \multicolumn{3}{|c|}{ Veins } & \multicolumn{2}{|c|}{$\begin{array}{c}\text { Phl-Ttn Granite }(-395 \\
\text { m) }\end{array}$} \\
\hline & Ttn8 & Ttn9 & Ttn10 & $T \operatorname{tn} 13$ & Ttn13_2 & Ttn1 & Ttn 4 & Ttn5 & Ttn14 & $T \operatorname{tn} 15$ \\
\hline $\mathrm{SiO}_{2}$ & 31.3 & 30.5 & 30.9 & 30.5 & 30.8 & 30.8 & 31.8 & 30.8 & 30.7 & 30.6 \\
\hline $\mathrm{TiO}_{2}$ & 33.6 & 33.9 & 32.0 & 35.0 & 33.6 & 33.4 & 31.2 & 34.4 & 33.9 & 34.2 \\
\hline $\mathrm{Al}_{2} \mathrm{O}_{3}$ & 3.70 & 3.15 & 4.26 & 2.64 & 3.85 & 3.68 & 5.55 & 2.92 & 3.41 & 2.76 \\
\hline $\mathrm{FeO}$ & 0.20 & 0.16 & 0.25 & 0.33 & 0.21 & 0.27 & 0.11 & 0.25 & 0.33 & 0.22 \\
\hline $\mathrm{MnO}$ & 0.00 & 0.03 & 0.00 & 0.06 & 0.02 & 0.05 & 0.01 & 0.04 & 0.01 & 0.02 \\
\hline $\mathrm{MgO}$ & 0.10 & 0.16 & 0.20 & 0.07 & 0.16 & 0.17 & 0.07 & 0.19 & 0.25 & 0.10 \\
\hline $\mathrm{CaO}$ & 28.5 & 26.9 & 27.3 & 27.9 & 27.1 & 27.9 & 28.6 & 27.0 & 27.7 & 27.5 \\
\hline $\mathrm{Na}_{2} \mathrm{O}$ & 0.02 & 0.08 & 0.04 & 0.04 & 0.07 & 0.03 & 0.00 & 0.06 & 0.09 & 0.05 \\
\hline $\mathrm{Nb}_{2} \mathrm{O}_{5}$ & 0.08 & 0.35 & 0.10 & 0.17 & 0.13 & 0.04 & 0.17 & 0.36 & 0.29 & 0.32 \\
\hline $\mathrm{La}_{2} \mathrm{O}_{3}$ & 0.03 & 0.14 & 0.15 & 0.19 & 0.12 & 0.05 & 0.00 & 0.22 & 0.12 & 0.22 \\
\hline $\mathrm{Ce}_{2} \mathrm{O}_{3}$ & 0.02 & 1.08 & 1.00 & 0.58 & 0.07 & 0.56 & 0.13 & 1.17 & 1.01 & 0.85 \\
\hline $\mathrm{Sm}_{2} \mathrm{O}_{3}$ & 0.16 & 0.15 & 0.06 & 0.18 & 0.04 & 0.00 & 0.01 & 0.14 & 0.14 & 0.03 \\
\hline $\mathrm{Nd}_{2} \mathrm{O}_{3}$ & 0.03 & 0.76 & 0.78 & 0.23 & 0.16 & 0.24 & 0.18 & 0.83 & 0.51 & 0.47 \\
\hline $\mathrm{F}$ & 0.55 & 0.35 & 0.49 & 0.41 & 0.46 & 0.48 & 0.79 & 0.31 & 0.45 & 0.25 \\
\hline Total & 100.7 & 99.9 & 99.6 & 100.6 & 99.2 & 100.0 & 100.7 & 100.7 & 101.2 & 99.9 \\
\hline \multicolumn{11}{|c|}{ Trace element (ppm)-LA-ICP-MS } \\
\hline $\mathrm{Li}$ & 5.2 & 24 & 9.5 & 15 & 1.81 & 11 & 5.3 & 9.4 & 6.8 & 6.7 \\
\hline $\mathrm{Be}$ & 0.02 & 1.10 & 0.22 & 1.67 & bdl & 0.20 & 0.08 & 0.16 & bdl & bdl \\
\hline Sc & 42 & 247 & 328 & 372 & 389 & 257 & 11 & 663 & 162 & 167 \\
\hline $\mathrm{V}$ & 920 & 1075 & 1476 & 1105 & 2398 & 1451 & 476 & 1487 & 1636 & 1661 \\
\hline $\mathrm{Cr}$ & 636 & 603 & 964 & 1323 & 1422 & 904 & 403 & 860 & 786 & 803 \\
\hline $\mathrm{Mn}$ & 87 & 169 & 155 & 168 & 99 & 191 & 90 & 154 & 116 & 118 \\
\hline Co & 0.11 & 0.15 & 0.17 & 0.21 & bdl & 0.12 & 0.11 & 0.11 & bdl & bdl \\
\hline $\mathrm{Ni}$ & 0.43 & 0.39 & 0.41 & 1.64 & 0.34 & 0.39 & 0.55 & 0.66 & 0.32 & 0.35 \\
\hline $\mathrm{Cu}$ & 9.0 & 9.3 & 8.4 & 8.9 & 8.1 & 8.0 & 8.6 & 8.4 & 7.8 & 8.2 \\
\hline $\mathrm{Zn}$ & 8.0 & 8.8 & 8.1 & 11 & 8.3 & 8.8 & 8.7 & 9.8 & 7.5 & 7.6 \\
\hline $\mathrm{Ga}$ & 18 & 66 & 60 & 54 & 27 & 41 & 16 & 47 & 22 & 22 \\
\hline $\mathrm{Rb}$ & 0.25 & bdl & 0.10 & 5.9 & bdl & 0.51 & 0.13 & 0.46 & bdl & 0.07 \\
\hline $\mathrm{Sr}$ & 17 & 31 & 23 & 16 & 15 & 22 & 20 & 25 & 16 & 16 \\
\hline $\mathrm{Y}$ & 633 & 733 & 726 & 1239 & 482 & 1487 & 540 & 777 & 797 & 818 \\
\hline $\mathrm{Zr}$ & 433 & 757 & 516 & 1710 & 1070 & 444 & 405 & 1313 & 965 & 966 \\
\hline $\mathrm{Nb}$ & 816 & 2440 & 843 & 1388 & 639 & 828 & 720 & 840 & 1913 & 1952 \\
\hline Sn & 246 & 91 & 74 & 245 & 133 & 43 & 243 & 108 & 407 & 391 \\
\hline $\mathrm{Sb}$ & bdl & bdl & 0.16 & 0.60 & bdl & 0.06 & 0.12 & 0.08 & 0.08 & bdl \\
\hline Cs & 0.21 & bdl & bdl & 0.62 & 0.02 & 0.26 & 0.08 & 0.08 & bdl & bdl \\
\hline $\mathrm{Ba}$ & 0.02 & 0.04 & 0.04 & 0.56 & bdl & 0.07 & 0.17 & 0.41 & bdl & 0.01 \\
\hline $\mathrm{La}$ & 282 & 2551 & 1816 & 2265 & 740 & 1558 & 168 & 1446 & 421 & 414 \\
\hline $\mathrm{Ce}$ & 1090 & 9910 & 7650 & 7110 & 2499 & 5540 & 688 & 6020 & 1679 & 1689 \\
\hline $\operatorname{Pr}$ & 175 & 1432 & 1181 & 994 & 336 & 771 & 116 & 906 & 268 & 269 \\
\hline $\mathrm{Nd}$ & 871 & 6420 & 5590 & 4410 & 1377 & 3502 & 628 & 4480 & 1212 & 1199 \\
\hline $\mathrm{Sm}$ & 247 & 1157 & 1044 & 1044 & 275 & 788 & 203 & 883 & 275 & 275 \\
\hline $\mathrm{Eu}$ & 6.2 & 3.8 & 3.6 & 11 & 9.6 & 5.6 & 5.7 & 3.9 & 13 & 13 \\
\hline $\mathrm{Gd}$ & 200 & 638 & 588 & 739 & 195 & 582 & 166 & 533 & 214 & 213 \\
\hline $\mathrm{Tb}$ & 28 & 55 & 50 & 84 & 23 & 73 & 23 & 48 & 32 & 32 \\
\hline Dy & 142 & 193 & 182 & 346 & 106 & 356 & 121 & 192 & 168 & 170 \\
\hline Ho & 24 & 27 & 27 & 51 & 18 & 56 & 20 & 28 & 30 & 30 \\
\hline $\mathrm{Er}$ & 58 & 61 & 62 & 110 & 44 & 133 & 50 & 65 & 75 & 76 \\
\hline $\mathrm{Tm}$ & 8.0 & 8.4 & 8.6 & 14 & 5.8 & 17 & 6.4 & 8.7 & 10 & 10 \\
\hline $\mathrm{Yb}$ & 47 & 61 & 67 & 86 & 38 & 104 & 39 & 62 & 63 & 63 \\
\hline $\mathrm{Lu}$ & 5.5 & 10 & 12 & 11 & 5.4 & 13 & 3.9 & 9.4 & 7.4 & 7.5 \\
\hline Hf & 47 & 38 & 32 & 114 & 70 & 34 & 27 & 72 & 61 & 61 \\
\hline $\mathrm{Ta}$ & 243 & 351 & 140 & 239 & 70 & 102 & 117 & 132 & 172 & 175 \\
\hline $\mathrm{Pb}$ & 0.26 & 1.46 & 0.39 & 3.9 & 0.24 & 0.43 & 0.70 & 0.51 & 0.28 & 0.27 \\
\hline $\mathrm{Bi}$ & 0.13 & 0.15 & 0.21 & 0.31 & 0.12 & 0.16 & 0.14 & 0.14 & 0.16 & 0.16 \\
\hline Th & 83 & 374 & 349 & 335 & 161 & 258 & 123 & 170 & 225 & 221 \\
\hline $\mathrm{U}$ & 151 & 276 & 313 & 244 & 267 & 394 & 196 & 177 & 395 & 392 \\
\hline
\end{tabular}

Note: For LA-ICP-MS data bdl $=$ below detection limit of $0.01 \mathrm{ppm}$ equal to $\mu \mathrm{g} \cdot \mathrm{g}^{-1}$. 
Rutile usually occurs as anhedral crystals in spatial relation with titanite, ilmenite, and metasomatized biotite (Figure 3). In the latter, rutile forms needle-shaped crystals between biotite cleavage planes. Titanium varies significantly from 90 to $99 \mathrm{wt} \%$, with high Ti corresponding to less bright areas in the back scattered electron images. Occasionally it is possible to observe octagonal, euhedral crystals, characterized by prominent zoning (Figure 9). Rutile crystals can reach sizes of up to $500 \mu \mathrm{m}$ (Figure 3), when they completely replace titanite crystals. The average chemical compositions of rutile are reported in the Supplementary Table S1. The analyzed samples show a significant amount of $\mathrm{Nb}(0.1-2.8 \mathrm{wt} \%), \mathrm{Cr}$ (up to $1.6 \mathrm{wt} \%), \mathrm{Fe}(<1 \mathrm{wt} \%), \mathrm{V}$ (500-3500 ppm), Al (500-1000 ppm), $\mathrm{Zr}(70-700 \mathrm{ppm}), \mathrm{Sc}(40-340 \mathrm{ppm})$, and Sn (100-200 ppm). Zoned crystals commonly show decreasing amounts of $\mathrm{Cr}, \mathrm{Zr}, \mathrm{Nb}$, and $\mathrm{Ta}$ from core to rim, which contrasts with the increasing Fe and Al. Low to no detectable concentrations of REE are recorded. The $\mathrm{Cr}$ vs. $\mathrm{Nb}$ diagram allows two populations of rutile to be distinguished, though the $\mathrm{Cr} / \mathrm{Nb}$ ratio does not change significantly.

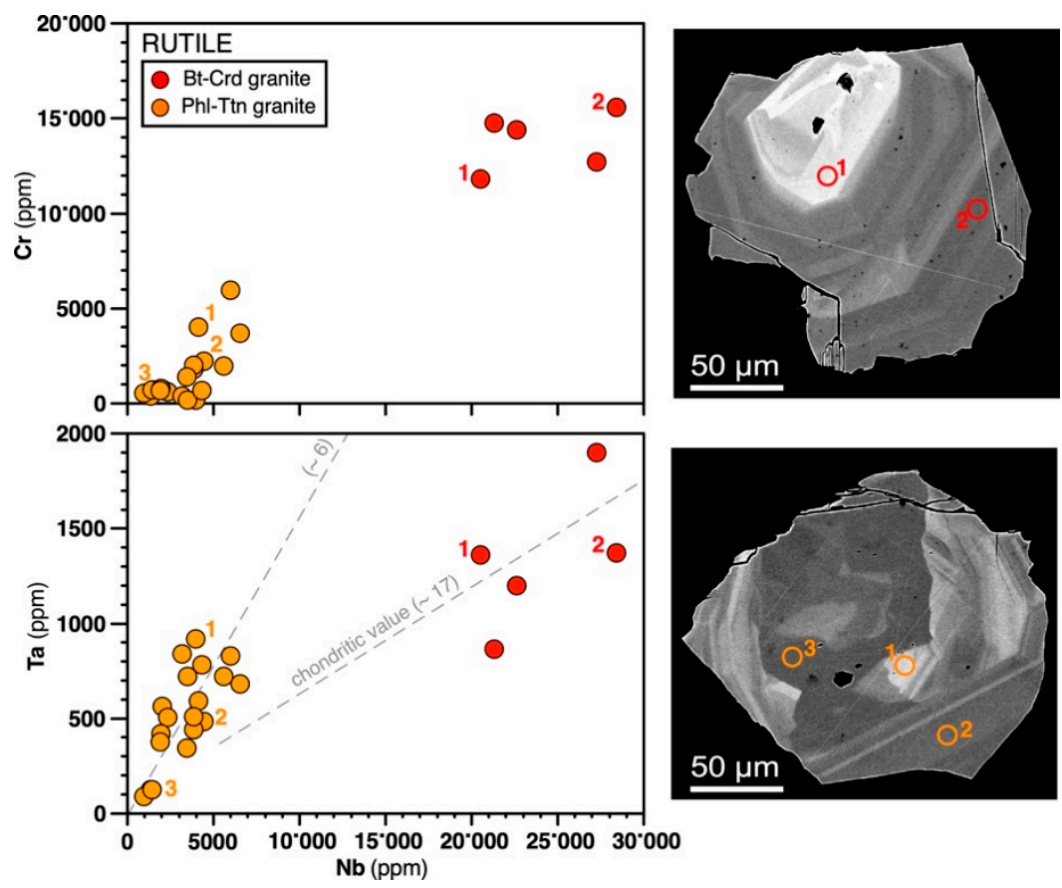

Figure 9. Compositional diagrams which show the mineral chemistry of metasomatic rutile crystallized in the granite during incipient metasomatism of the ilmenite and titanite in the biotite-cordierite granite (red) and in the phlogopite-titanite granite (orange). The diagrams show the tendency of Ta to decouple from $\mathrm{Nb}$ (chondritic $\mathrm{Ta} / \mathrm{Nb}=17.6$, [26]). On the right, back-scattered electron images show the strong, complex zoning observed in rutile crystals.

\subsubsection{Calc-Silicate Minerals (Pyroxene, Vesuvianite, Garnet, Epidote Group Minerals)}

The metasomatic calc-silicates minerals are mainly represented by vesuvianite, diopside, garnet, titanite, epidote group minerals, as well as phlogopite, scapolite, and zircon. Other metasomatic minerals are fluorapatite, sulfides, fluorite, and minor cheralite. Multiple fluid-mineral exchange reactions are pointed out by (i) the diffuse growth zonation of the calc-silicates (garnet, vesuvianite, allanite, and titanite), (ii) the multi-stage replacement of calc-silicate minerals (i.e., epidote $\rightarrow$ allanite; cheralite $\rightarrow$ thorite + quartz), and (iii) the occurrence of metasomatic zircon, apatite, uraninite, and thorite, replacing intensively metasomatized calc-silicates (e.g., titanite) [1].

The typical metasomatic assemblage in the diopside-rich zone is diopside + titanite + calcite+ quartz + epidote $\pm \mathrm{K}$-feldspar \pm plagioclase, with variable abundances of sulfides. Back scattered electron images and SEM-EDS analyzed pyroxene collected from the Campiglia metasomatic bodies show a wide range of Ca-Mg-Fe pyroxene compositions, mostly falling in the diopside-hedenbergite 
field. This is seen in abundances of Fe (3-22 wt \%) and $\mathrm{Mg}(3-16 \mathrm{wt} \%)$, such that pyroxene compositions range from $\mathrm{En}_{35-45}$ to $\mathrm{En}_{15-10}$. Pyroxenes from exoskarn bodies, at the pluton-marble contact, show enrichment in Fe with respect to $\mathrm{Mg}$. In contrast, pyroxene from the endoskarn shows a diopsidic composition with the $\mathrm{Mg}$ content higher than Fe. Hedenbergite, from vesuvianite rich bodies, and diopside, from diopside bearing exoskarn, are clearly distinguishable from the $\mathrm{Mg \#} \mathrm{vs.} \mathrm{CaO} \mathrm{diagram.}$ Variations in the $\mathrm{Fe}$ and $\mathrm{Mg}$ concentration occasionally produce growth zoning, which do not reflect other chemical changes (Figure $3 \mathrm{C}$ ). The $\mathrm{Al}$ content is commonly lower than $0.5 \mathrm{wt} \%$. Other trace elements detected by LA-ICP-MS are Mn (500-5000 ppm), Ti (0-500 ppm), Na (0-1300 ppm), and Zn (40-400 ppm). The content of F, REE, and HFSE show values close to the detection limit or below it (Table 4). Despite the low REE content, diopside and hedenbergite crystals clearly show different REE patterns, with the hedenbergite crystals relatively enriched in the LREE. Pyroxene is occasionally associated with small, interstitial amphibole (Figure 10A).
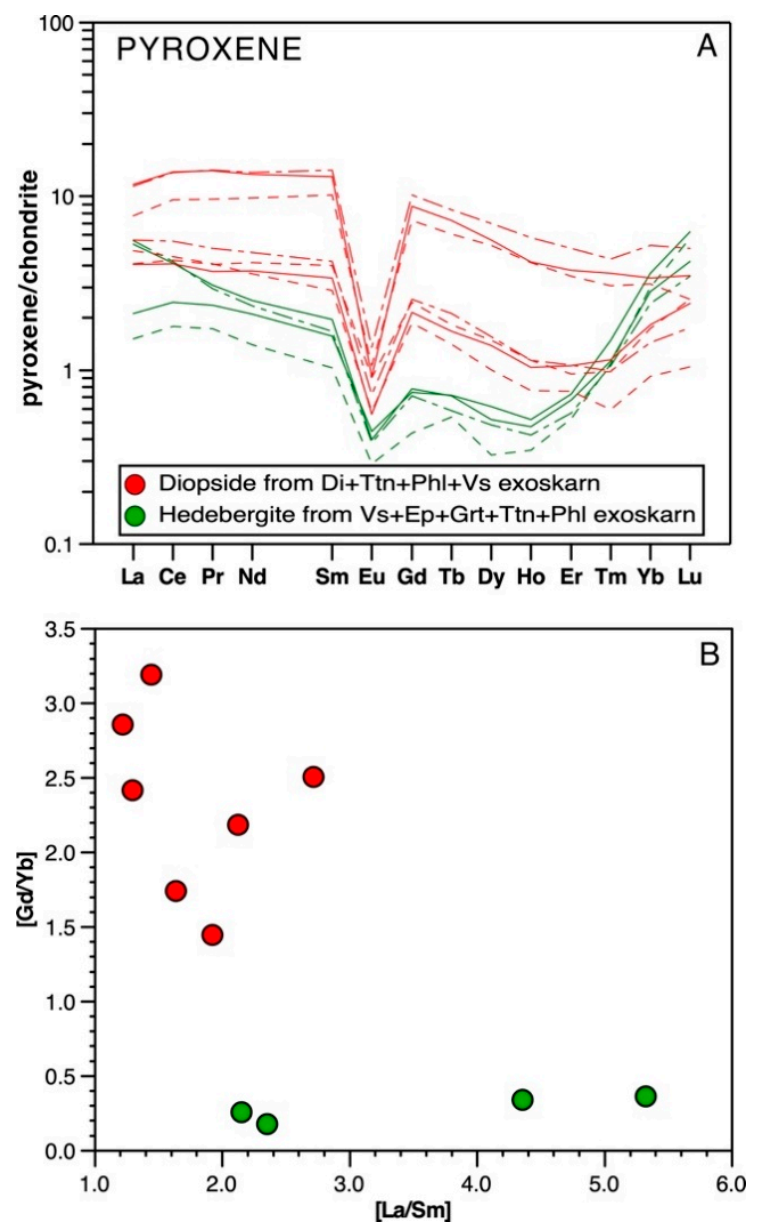

Figure 10. (A) Chondrite-normalized REE patterns for metasomatic clinopyroxene. Despite the low value of REE for both groups, hedenbergite from Vesuvianite-rich exoskarn shows different fractionations of both LREE and HREE, as evidenced by the (B) Gd/Yb vs La/Sm diagram. Chondrite normalization values are taken from [25].

The chemistry of and chemical variations in vesuvianite crystals from the exoskarn samples have been examined by electron microprobe analysis. For 24 analyses, the mean $\mathrm{Si}$ content is 18.05 a.p.f.u., indicating that only $\mathrm{Si}$ occurs in the Z-group sites. The mean $\mathrm{Ca}+\mathrm{Na}+\mathrm{La}+\mathrm{Pb}+\mathrm{Th}$ content is 18.3 a.p.f.u., that indicate possible substitutions in the $\mathrm{X}$ site (usually 19). The mean $\mathrm{Al}+\mathrm{Mg}+\mathrm{Fe}+\mathrm{Ti}$ $+\mathrm{Mn}+\mathrm{Cu}+\mathrm{Zn}$ content is 12.99 a.p.f.u., indicating that only these cations occupy the Y group site. 
Table 4. Electron microprobe and LA-ICP-MS analyses for pyroxene crystals from BM.

\begin{tabular}{|c|c|c|c|c|c|c|}
\hline \multirow{2}{*}{$\begin{array}{c}\text { Rock } \\
\text { Mineral }\end{array}$} & \multicolumn{3}{|c|}{ Exoskarn } & \multicolumn{3}{|c|}{ Endoskarn } \\
\hline & Cpx1_rim & Cpx2_core & Cpx2_rim & Px27_rim & Px27_mid & Px27_core \\
\hline $\mathrm{SiO}_{2}$ & 51.0 & 51.8 & 50.7 & 53.7 & 55.1 & 55.2 \\
\hline $\mathrm{TiO}_{2}$ & 0.06 & 0.00 & 0.03 & 0.00 & 0.00 & 0.09 \\
\hline $\mathrm{Al}_{2} \mathrm{O}_{3}$ & 0.28 & 0.13 & 0.36 & 0.22 & 0.18 & 0.05 \\
\hline $\mathrm{Cr}_{2} \mathrm{O}_{3}$ & $\mathrm{Nd}$ & nd & nd & nd & nd & nd \\
\hline $\mathrm{FeO}$ & 22.9 & 18.9 & 23.3 & 8.18 & 2.98 & 2.28 \\
\hline Mno & 0.56 & 0.48 & 0.55 & 0.22 & 0.07 & 0.04 \\
\hline $\mathrm{MgO}$ & 3.18 & 6.01 & 3.58 & 13.1 & 16.3 & 16.9 \\
\hline $\mathrm{CaO}$ & 23.1 & 22.9 & 23.2 & 25.0 & 25.2 & 25.5 \\
\hline $\mathrm{Na}_{2} \mathrm{O}$ & 0.10 & 0.12 & 0.09 & 0.11 & 0.00 & 0.00 \\
\hline $\mathrm{K}_{2} \mathrm{O}$ & 0.00 & 0.00 & 0.00 & 0.00 & 0.01 & 0.00 \\
\hline $\mathrm{F}$ & nd & nd & nd & nd & nd & nd \\
\hline$M g \#$ & nd & nd & nd & nd & nd & nd \\
\hline $\mathrm{Fe \#}$ & nd & nd & nd & nd & nd & nd \\
\hline Total & 101.2 & 100.6 & 101.9 & 100.7 & 100.0 & 100.2 \\
\hline \multicolumn{7}{|c|}{ Trace element (ppm)—LA-ICP-MS } \\
\hline $\mathrm{Li}$ & 56 & 89 & 55 & 106 & 34 & 9.82 \\
\hline $\mathrm{Be}$ & 1.54 & 3.29 & 1.93 & 4.30 & 19 & 17 \\
\hline Sc & 5.47 & 5.60 & 5.47 & 5.38 & 5.44 & 5.77 \\
\hline $\mathrm{V}$ & 17 & 27 & 16 & 18 & 16 & 10 \\
\hline $\mathrm{Cr}$ & 9.25 & 7.70 & 6.80 & 2.57 & 1.40 & 3.06 \\
\hline $\mathrm{Mn}$ & 4740 & 5113 & 4831 & 1532 & 612 & 468 \\
\hline $\mathrm{Co}$ & 21 & 12.1 & 20 & 11 & 2.34 & 1.89 \\
\hline $\mathrm{Ni}$ & 5.70 & 5.33 & 3.30 & 24 & 1.71 & 0.36 \\
\hline $\mathrm{Cu}$ & bdl & 0.21 & bdl & 0.27 & 0.44 & 0.26 \\
\hline $\mathrm{Zn}$ & 410 & 397 & 421 & 116 & 44 & 35 \\
\hline $\mathrm{Ga}$ & 6.23 & 5.69 & 7.13 & 4.15 & 4.68 & 2.67 \\
\hline $\mathrm{Rb}$ & bdl & bdl & bdl & 1.80 & 1.03 & 0.09 \\
\hline $\mathrm{Sr}$ & 22 & 20 & 25 & 15 & 12 & 11 \\
\hline $\mathrm{Y}$ & 0.78 & 0.51 & 0.84 & 1.60 & 8.95 & 6.10 \\
\hline $\mathrm{Zr}$ & 5.89 & 2.35 & 8.38 & 4.14 & 11 & 3.37 \\
\hline $\mathrm{Nb}$ & 0.00 & bdl & 0.01 & 0.01 & 0.31 & 0.01 \\
\hline Sn & 6.19 & 5.38 & 8.73 & 6.32 & 7.81 & 2.11 \\
\hline $\mathrm{Sb}$ & 0.05 & 0.05 & 0.07 & 0.37 & 0.18 & 0.04 \\
\hline Cs & bdl & 0.03 & bdl & 3.94 & 1.41 & 0.05 \\
\hline $\mathrm{Ba}$ & 0.03 & 0.02 & 0.02 & 1.57 & 0.78 & 0.02 \\
\hline $\mathrm{La}$ & 1.26 & 0.34 & 1.31 & 0.96 & 2.72 & 1.84 \\
\hline $\mathrm{Ce}$ & 2.54 & 1.03 & 2.59 & 2.52 & 8.44 & 5.86 \\
\hline $\operatorname{Pr}$ & 0.29 & 0.15 & 0.27 & 0.34 & 1.31 & 0.90 \\
\hline $\mathrm{Nd}$ & 1.15 & 0.60 & 1.08 & 1.71 & 6.26 & 4.49 \\
\hline $\mathrm{Sm}$ & 0.29 & 0.14 & 0.25 & 0.50 & 2.10 & 1.51 \\
\hline $\mathrm{Eu}$ & 0.02 & 0.02 & 0.02 & 0.03 & 0.08 & 0.06 \\
\hline $\mathrm{Gd}$ & 0.16 & 0.08 & 0.14 & 0.43 & 2.03 & 1.44 \\
\hline $\mathrm{Tb}$ & 0.03 & 0.02 & 0.02 & 0.06 & 0.30 & 0.22 \\
\hline Dy & 0.13 & 0.08 & 0.12 & 0.34 & 1.72 & 1.28 \\
\hline Ho & 0.03 & 0.02 & 0.02 & 0.06 & 0.32 & 0.23 \\
\hline $\mathrm{Er}$ & 0.11 & 0.08 & 0.09 & 0.17 & 0.80 & 0.56 \\
\hline $\mathrm{Tm}$ & 0.03 & 0.03 & 0.03 & 0.03 & 0.11 & 0.08 \\
\hline $\mathrm{Yb}$ & 0.46 & 0.45 & 0.39 & 0.30 & 0.84 & 0.51 \\
\hline $\mathrm{Lu}$ & 0.10 & 0.13 & 0.09 & 0.06 & 0.12 & 0.06 \\
\hline $\mathrm{Hf}$ & 0.31 & 0.22 & 0.42 & 0.25 & 0.28 & 0.12 \\
\hline $\mathrm{Ta}$ & bdl & 0.00 & 0.00 & 0.00 & 0.34 & 0.01 \\
\hline $\mathrm{Pb}$ & 0.21 & 0.14 & 0.18 & 0.40 & 0.76 & 0.10 \\
\hline $\mathrm{Bi}$ & 0.01 & 0.01 & 0.01 & 0.05 & 0.05 & 0.01 \\
\hline Th & 0.02 & 0.01 & 0.01 & 0.13 & 0.08 & 0.01 \\
\hline $\mathrm{U}$ & 0.01 & 0.02 & 0.02 & 0.09 & 0.06 & 0.01 \\
\hline
\end{tabular}

Note: $\mathrm{nd}=$ not detected; $\mathrm{bdl}=$ below detection limit of $0.01 \mathrm{ppm}$. 
It is possible to distinguish between three distinctly different vesuvianite groups. Vesuvianite from diopside + titanite + phlogopite \pm vesuvianite shows homogeneous crystals with typical compositions [27]. Vesuvianite from the vesuviante + epidote exoskarn shows two geochemically distinct groups of REE-enriched crystals, mostly distinguishable by their contrasting Eu anomaly. Finally, vesuvianite from the vesuvianite+garnet exoskarn shows scattered values without a clear trend (Figure 11A-E). REE-rich vesuvianite is observed indistinctly in all the exoskarn lithologies. The impurities detected by LA-ICP-MS are Zn (100-200 ppm), Li-Be (100-2000 ppm), and Zr (30-400 ppm), as well as $\mathrm{Bi}, \mathrm{Sn}$, and $\mathrm{Sb}$ with values of ca. $50 \mathrm{ppm}$. Vesuvianite crystals from the diopside + epidote + vesuvianite + quartz + calcite exoskarn show the highest values of REE accompanied by the highest value of Th (up to $2500 \mathrm{ppm}$ ) and U (up to $3900 \mathrm{ppm}$ ), replacing Ca in the $X$ site (Figure 10). These elements also appear in high concentrations in vesuvianite crystals from the other environments ( $\mathrm{Th}=0.5-5000 \mathrm{ppm} ; \mathrm{U}=1.5-580 \mathrm{ppm}$ ). Vesuvianite from the vesuvianite-garnet-rich exoskarn shows a prominent growth zoning with significant variability in the $U$, Th, and REE content. Some crystals show maximum values for these elements in the inner rim, compared with the outer rim and the core, and a positive correlation between $U$ and REE. Other crystals show an increase in $U$ and Th from the rim to the core with a negative correlation for the REE content. Moreover, all the analyzed vesuvianite contains notable amounts of $\mathrm{F}(0.68-0.88 \mathrm{wt} \%)$, probably replacing $\mathrm{OH}^{-}$or $\mathrm{O}$.
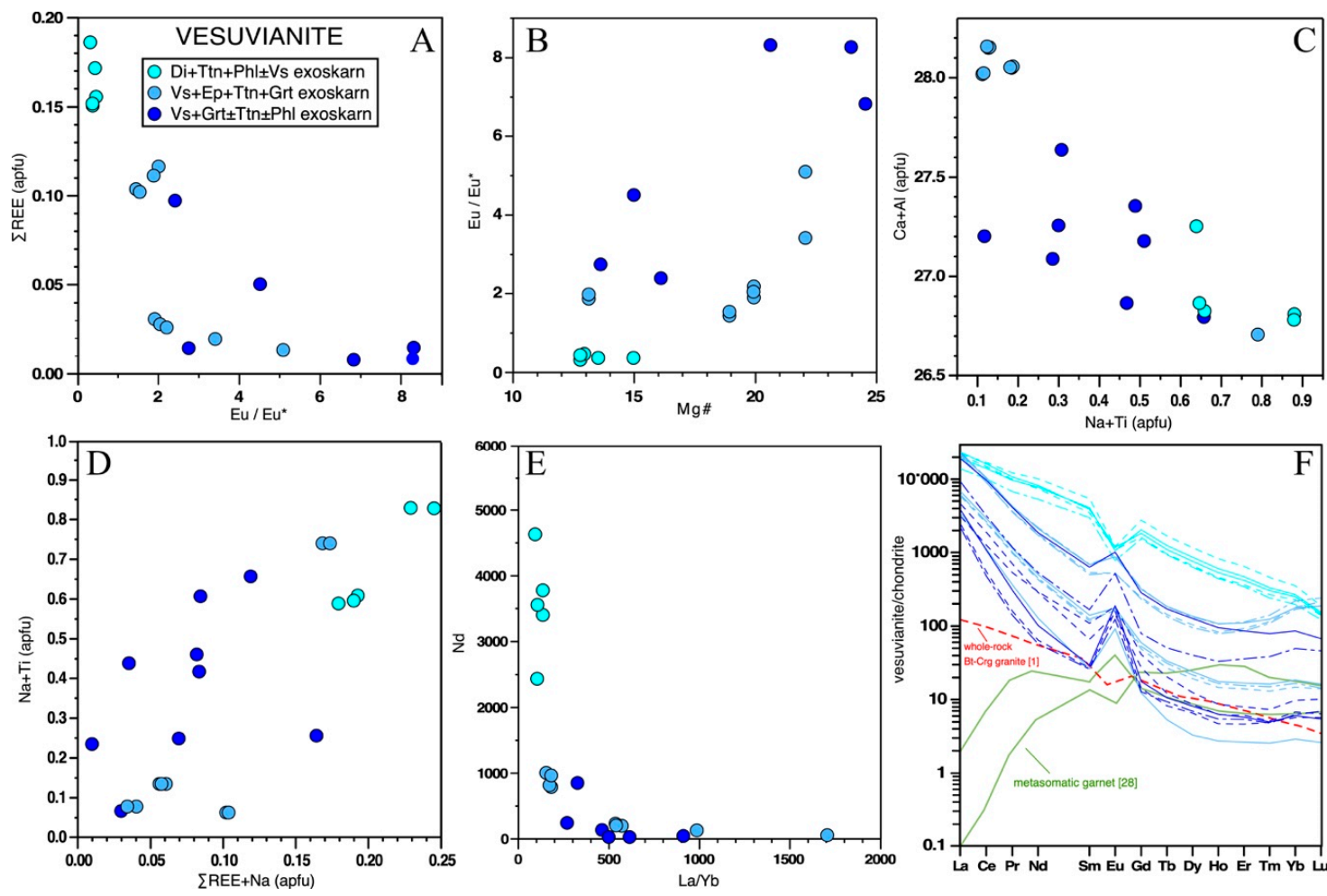

Figure 11. Diagrams showing the mineral chemistry of metasomatic vesuvianite from different exoskarn typologies. Diagrams from (A) to (E) show the correlation between REE, U, Ti, Mg, Ca, Na, and Al. In (F) Chondrite-normalized REE pattern for vesuvianite from different exoskarn typologies. It is possible to observe two different REE profiles (see text for discussion). For comparison, whole-rock (WR) data from reference [1] and metasomatic garnet from reference [28]. Normalizing chondrite values are taken from reference [25].

The vesuvianite chondrite-normalized REE patterns (Figure 11F) highlight almost two distinctly different profiles, both enriched in LREE and depleted in HREE. The patterns obtained from vesuvianite crystals sampled from diopside-bearing exoskarn show a constant slope from enriched LREE to depleted HREE, with a strong negative Eu anomaly $\left(\mathrm{Eu} / \mathrm{Eu}^{*}=0.31-0.44\right)$. These crystals show higher values of $\mathrm{Nd}$ in contrast to a low La/Y ratio. The other crystals, separated from vesuvianite+garnet-rich 
exoskarn, show profiles characterized by a marked LREE slope, strong depletion in the middle REE, and a flat HREE pattern, with a prominently positive Eu anomaly $\left(\mathrm{Eu} / \mathrm{Eu}^{*}=1.9-8.3\right)$ and decreasing $\mathrm{Nd}$ values with an increasing La/Y ratio. REE patterns show a weak negative Eu anomaly for vesuvianite enriched in REE but strong positive Eu anomalies for vesuvianite crystals with a lower REE content (Table 5).

Garnet-pyroxene exoskarn bodies are predominant at the pluton-host contact [1]. More than one generation of garnet has been identified in an area $1 \mathrm{~mm}$ square, indicating the extremely dynamic nature of the metasomatic system. Commonly, garnet is red to brownish, anisotropic, and exhibits low birefringence. Oscillatory zoned garnet shows a morphological transition from simple dodecahedral growth in the core, to a composite dodecahedral trapezohedron growth near its margin. Anisotropy is not always homogeneous or sectorial and chaotic birefringence, development of lamellae, and irregular boundaries between sectors have been also observed. SEM-EDS analysis on garnet from the Campiglia exoskarns indicate a solid solution between grossular and andradite. The compositions range from $\mathrm{Adr}_{30} \mathrm{Grs}_{70}$ to almost pure grossular $\mathrm{Adr}_{1} \mathrm{Grs}_{99}$, with spessartine, pyrope, almandine, uvarovite, etc. collectively lower than $10 \%$. Rare $\mathrm{Adr}_{70} \mathrm{Grs}_{30}$ to almost pure andradites also occur (Supplementary Table S1). Slight variations are observed between (i) garnet from the pyroxene-garnet exoskarn, showing pyralspite up to $12 \%$, grossular up to $90 \%$, and andradite between $0-15 \%$, (ii) zoned garnet, showing pyralspite between $0-7 \%$ with a mainly grossular content, and (iii) garnet from the diopside + titanite + calcite + quartz \pm episode \pm vesuvianite exoskarn, showing a pyralspite content lower than $10 \%$. Garnet with oscillatory zoning usually shows Al-rich cores and Fe-rich rims, but homogeneous garnet and garnet with Fe-rich cores and Al-rich rims can also be found [29-31].

Epidote group minerals are common in the endoskarn and exoskarn, as well as frequently observed in the metasomatized granite [1]. This phase is characterized by multiple generations showing significant chemical variability. Figure 12 displays two different types of epidote group minerals. The first, collected from a diopside-bearing exoskarn, shows values of REE $<0.2$ a.p.f.u. and $\mathrm{Fe}^{3+}>0.8$, which allows the mineral to be classified as epidote $\left(\mathrm{Al}^{3+}>\mathrm{Fe}^{3+}\right)$. The other, consisting of crystals from a metasomatized granite and vesuvianite-bearing exoskarn, generally shows values of REE $>0.5$ a.p.f.u. and $\mathrm{Fe}^{3+}<0.5$ a.p.f.u., placing the mineral in the allanite subgroup (Table 5). In this context, the diopside-bearing exoskarn shows both epidote and allanite, with an evident increase in REE moving from the core to the rim of the crystals. On the other hand, allanite-(La, Ce) from the granite and the vesuvianite-bearing exoskarn is more homogeneous, showing only a slight enrichment in REE and Fe moving from the core to the rim, notably in samples from the granite body. The overall result is an increase in the REE concentration with a decreasing Ca concentration, marking the transition from epidote to allanite. The average composition of epidote shows an occasional enrichment in Sr (800-1000 ppm), Sn (1700-3000 ppm), and Sb (up to $450 \mathrm{ppm}$ ) for samples from the diopside + phlogopite + titanite + calcite \pm vesuvianite \pm epidote exoskarn. At the same time this epidote shows a low Th/U ratio $(<0.5)$, due to extremely low values of Th $(0.4-5 \mathrm{ppm})$. In contrast, the average composition of allanite from the metasomatized granite and from the endoskarn shows a higher $\mathrm{Th} / \mathrm{U}$ ratio, with commonly higher values of Th (50-1930 ppm) than U (40-200 ppm). This group shows also the highest value of REE (12-26 wt \%). REE show a positive correlation with the Th/U ratio and $\mathrm{F}$ values. Allanite shows the highest values of F (up to $0.4 \mathrm{wt} \%$ ). Allanite epidote crystals have strongly fractionated REE profiles, with a spoon-shaped HREE profile and a negative Eu anomaly. On the other side, allanite from Di-Grt-Vs bearing exoskarn is characterized by a less-fractionated pattern (Figure 12F,G). 
Table 5. Electron microprobe and LA-ICP-MS analyses for vesuvianite and epidote-group crystals from the BM mine.

\begin{tabular}{|c|c|c|c|c|c|c|c|c|c|c|c|c|}
\hline \multirow{2}{*}{$\begin{array}{c}\text { Rock } \\
\text { Mineral }\end{array}$} & \multicolumn{2}{|c|}{ Di Exoskarn (GBM46) } & \multicolumn{4}{|c|}{ Grt-Vs Exoskarn (STAB1) } & \multicolumn{6}{|c|}{ Vs Exoskarn (GBM45) } \\
\hline & Vs7_core & Vs7_rim & Vs1.1 & Vs1.2 & Vs 2.1 & Vs 2.1 & Ep1 & Ep4_core & Ep4_rim & All3.5_core & All3.5_mid & All3.5_rim \\
\hline $\mathrm{SiO}_{2}$ & 36.2 & 36.0 & 37.0 & 36.9 & 36.2 & 35.8 & 36.6 & 38.0 & 37.5 & 34.0 & 33.5 & 33.6 \\
\hline $\mathrm{TiO}_{2}$ & 1.49 & 2.06 & 0.29 & 1.85 & 1.64 & 1.44 & 0.01 & 0.00 & 0.29 & 0.28 & 0.36 & 0.21 \\
\hline $\mathrm{Al}_{2} \mathrm{O}_{3}$ & 15.2 & 14.9 & 16.9 & 15.1 & 15.1 & 14.9 & 19.6 & 19.6 & 19.6 & 20.7 & 20.0 & 18.4 \\
\hline $\mathrm{FeO}$ & 6.34 & 6.22 & 5.34 & 6.82 & 7.04 & 6.73 & 15.5 & 16.3 & 16.4 & 8.24 & 8.88 & 8.86 \\
\hline $\mathrm{MnO}$ & 0.43 & 0.11 & 0.07 & 0.09 & 0.10 & 0.19 & 0.29 & 0.10 & 0.08 & 0.10 & 0.12 & 0.07 \\
\hline $\mathrm{MgO}$ & 0.99 & 0.91 & 1.33 & 1.03 & 0.72 & 1.11 & 0.00 & 0.00 & 0.00 & 1.21 & 1.25 & 2.11 \\
\hline $\mathrm{CaO}$ & 33.6 & 33.8 & 35.3 & 34.2 & 32.4 & 33.0 & 19.5 & 22.7 & 21.3 & 13.2 & 12.6 & 11.1 \\
\hline $\mathrm{Na}_{2} \mathrm{O}$ & 0.04 & 0.06 & 0.03 & 0.06 & 0.09 & 0.06 & 0.00 & 0.00 & 0.00 & 0.00 & 0.00 & 0.00 \\
\hline $\mathrm{Nb}_{2} \mathrm{O}_{5}$ & 0.00 & 0.00 & 0.00 & 0.00 & 0.00 & 0.00 & 0.12 & 0.08 & 0.01 & 0.67 & 0.60 & 0.60 \\
\hline $\mathrm{La}_{2} \mathrm{O}_{3}$ & 0.57 & 0.47 & 0.06 & 0.60 & 0.59 & 0.59 & 4.05 & 0.25 & 2.25 & 7.95 & 8.34 & 10.6 \\
\hline $\mathrm{Ce}_{2} \mathrm{O}_{3}$ & 1.01 & 0.86 & 0.16 & 0.79 & 1.52 & 1.43 & 2.04 & 0.17 & 1.28 & 10.4 & 11.4 & 12.1 \\
\hline $\mathrm{Sm}_{2} \mathrm{O}_{3}$ & 0.12 & 0.02 & 0.00 & 0.05 & 0.14 & 0.00 & 0.00 & 0.00 & 0.06 & 0.05 & 0.03 & 0.05 \\
\hline $\mathrm{Nd}_{2} \mathrm{O}_{3}$ & 0.32 & 0.28 & 0.17 & 0.10 & 0.68 & 0.36 & 0.06 & 0.00 & 0.13 & 1.73 & 1.88 & 1.79 \\
\hline F & 0.72 & 0.84 & 0.88 & 0.73 & 0.73 & 0.73 & 0.03 & 0.00 & 0.00 & 0.13 & 0.19 & 0.35 \\
\hline Total & 97.4 & 96.6 & 97.5 & 98.3 & 97.0 & 96.4 & 97.7 & 97.3 & 98.8 & 98.5 & 99.0 & 99.4 \\
\hline \multicolumn{13}{|c|}{ Trace element (ppm)_LA-ICP-MS } \\
\hline $\mathrm{Li}$ & 272 & 194 & 114 & 157 & 206 & 171 & 4.0 & 4.2 & 7.4 & 244 & 125 & 254 \\
\hline $\mathrm{Be}$ & 147 & 173 & 82 & 57 & 275 & 162 & 0.40 & 0.40 & 2.80 & 0.20 & 0.40 & 0.20 \\
\hline Sc & 3.31 & 3.6 & 6.8 & 5.6 & 4.7 & 3.7 & 5.6 & 5.2 & 7.1 & 6.5 & 6.2 & 6.2 \\
\hline $\mathrm{V}$ & 95 & 84 & 11.6 & 140 & 73 & 14.1 & 12.0 & 81 & 13.0 & 120 & 98 & 106 \\
\hline $\mathrm{Cr}$ & 35 & 29.3 & 29.4 & 17.6 & 2.08 & 3.5 & bdl & 6.2 & 3.20 & 6.6 & 3.6 & 4.9 \\
\hline $\mathrm{Mn}$ & 998 & 1106 & 1080 & 1066 & 1144 & 1092 & 1455 & 1322 & 19,200 & 914 & 837 & 921 \\
\hline Co & 5.1 & 5.1 & 2.64 & 4.3 & 5.4 & 3.29 & bdl & bdl & 5.4 & 2.20 & 2.30 & 2.40 \\
\hline $\mathrm{Ni}$ & 10.9 & 0.64 & 0.86 & 0.75 & 6.67 & 1.03 & 2.10 & 0.80 & 5.0 & bdl & Bdl & bdl \\
\hline $\mathrm{Cu}$ & 0.54 & 0.52 & bdl & 0.58 & 0.31 & bdl & bdl & bdl & 2.90 & bdl & Bdl & bdl \\
\hline $\mathrm{Zn}$ & 135 & 142 & 98 & 118 & 117 & 109 & 26 & 34 & 99 & 78 & 65 & 77 \\
\hline $\mathrm{Ga}$ & 85 & 99 & 50 & 77 & 115 & 49 & 117 & 85 & 10 & 683 & 683 & 642 \\
\hline $\mathrm{Rb}$ & bdl & 2.26 & bdl & 0.07 & 0.13 & bdl & bdl & bdl & 1.80 & bdl & 0.20 & 1.10 \\
\hline $\mathrm{Sr}$ & 45 & 56 & 55 & 53 & 49 & 55 & 1051 & 1098 & 152 & 221 & 210 & 197 \\
\hline $\mathrm{Y}$ & 587 & 769 & 26.61 & 170 & 1474 & 59 & 250 & 211 & 16 & 168 & 123 & 150 \\
\hline $\mathrm{Zr}$ & 13.1 & 28.5 & 344 & 120 & 38 & 24.8 & 12.0 & 26.0 & 2.40 & 2.40 & 2.90 & 3.20 \\
\hline
\end{tabular}


Table 5. Cont.

\begin{tabular}{|c|c|c|c|c|c|c|c|c|c|c|c|c|}
\hline \multirow{2}{*}{$\begin{array}{c}\text { Rock } \\
\text { Mineral }\end{array}$} & \multicolumn{2}{|c|}{ Di Exoskarn (GBM46) } & \multicolumn{4}{|c|}{ Grt-Vs Exoskarn (STAB1) } & \multicolumn{6}{|c|}{ Vs Exoskarn (GBM45) } \\
\hline & Vs7_core & Vs7_rim & Vs1.1 & Vs1.2 & Vs 2.1 & Vs 2.1 & Ep1 & Ep4_core & Ep4_rim & All3.5_core & All3.5_mid & All3.5_rim \\
\hline \multicolumn{13}{|c|}{ Trace element (ppm)-LA-ICP-MS } \\
\hline $\mathrm{Nb}$ & 0.70 & 2.07 & 9.37 & 3.62 & 1.88 & 1.34 & 0.06 & 0.03 & 0.01 & 0.02 & 0.02 & 0.03 \\
\hline Sn & 42 & 71 & 45 & 79 & 42 & 37 & 1753 & 1900 & 190 & 22.0 & 85 & 24.0 \\
\hline $\mathrm{Sb}$ & 69 & 71 & 49 & 61 & 61 & 58 & 453 & 28.0 & 10.0 & bdl & Bdl & bdl \\
\hline Cs & bdl & 2.09 & bdl & bdl & 0.01 & bdl & 0.04 & bdl & 1.12 & bdl & 0.07 & 0.54 \\
\hline $\mathrm{Ba}$ & 0.00 & 0.24 & 0.00 & 0.02 & 0.03 & bdl & 1.30 & 0.47 & 3.9 & 0.13 & 0.20 & 1.30 \\
\hline $\mathrm{Ce}$ & 6120 & 9830 & 1523 & 6340 & 12,310 & 1308 & 30,300 & 19,700 & 1370 & 105,800 & 88,300 & 97,100 \\
\hline $\operatorname{Pr}$ & 625 & 995 & 92 & 393 & 1296 & 99 & 1248 & 753 & 53 & 6677 & 6000 & 6030 \\
\hline $\mathrm{Nd}$ & 2435 & 3780 & 197 & 1003 & 4770 & 301 & 2140 & 1430 & 81 & 15,690 & 14,590 & 14,090 \\
\hline Sm & 443 & 577 & 17.4 & 103 & 754 & 47 & 162 & 133 & 8.8 & 1092 & 1063 & 977 \\
\hline $\mathrm{Eu}$ & 44 & 66 & 9.3 & 53 & 96 & 10.8 & 12.9 & 17.7 & 1.39 & 23.4 & 24.1 & 20.9 \\
\hline $\mathrm{Gd}$ & 306 & 365 & 9.7 & 65 & 495 & 30.2 & 146 & 136 & 10.0 & 557 & 488 & 508 \\
\hline $\mathrm{Tb}$ & 34 & 40 & 0.98 & 6.6 & 61 & 3.33 & 11.9 & 13.1 & 0.72 & 30.4 & 26.2 & 27.8 \\
\hline Dy & 157 & 188 & 4.7 & 32.6 & 318 & 14.8 & 50 & 53 & 3.00 & 76 & 61 & 67 \\
\hline Ho & 24.2 & 29.1 & 0.8 & 5.8 & 54 & 2.1 & 9.2 & 8.1 & 0.50 & 7.9 & 6.0 & 7.1 \\
\hline $\mathrm{Tm}$ & 6.0 & 7.5 & 0.3 & 3.5 & 16.8 & 0.51 & 4.2 & 2.00 & 0.24 & 1.20 & 0.91 & 1.10 \\
\hline $\mathrm{Yb}$ & 31.6 & 40 & 2.4 & 35 & 89 & 2.8 & 31.0 & 11.0 & 3.00 & 6.9 & 5.2 & 6.0 \\
\hline $\mathrm{Lu}$ & 3.03 & 3.6 & 0.34 & 6.0 & 7.4 & 0.28 & 4.6 & 1.50 & 0.60 & 0.85 & 0.65 & 0.74 \\
\hline Hf & 0.50 & 1.04 & 4.3 & 2.71 & 1.49 & 0.53 & 0.39 & 1.50 & 0.22 & 0.25 & 0.29 & 0.30 \\
\hline $\mathrm{Ta}$ & 0.04 & 0.16 & 1.18 & 0.63 & 0.37 & 0.30 & 0.03 & 0.01 & 0.03 & 0.01 & 0.02 & 0.01 \\
\hline $\mathrm{Pb}$ & 2.10 & 1.98 & 0.70 & 1.04 & 0.96 & 0.86 & 1.70 & 0.49 & 4.10 & 0.41 & 0.25 & 1.10 \\
\hline $\mathrm{Bi}$ & 49 & 47 & 30.7 & 63 & 44 & 37 & 17.0 & 1.70 & 0.38 & 0.05 & 0.09 & 0.07 \\
\hline Th & 2521 & 94 & 1.9 & 48 & 12.8 & 35 & 0.64 & 2.70 & 0.41 & 585 & 53 & 393 \\
\hline $\mathrm{U}$ & 2016 & 2442 & 16.6 & 203 & 4119 & 156 & 66 & 129 & 11.0 & 194 & 55 & 182 \\
\hline
\end{tabular}



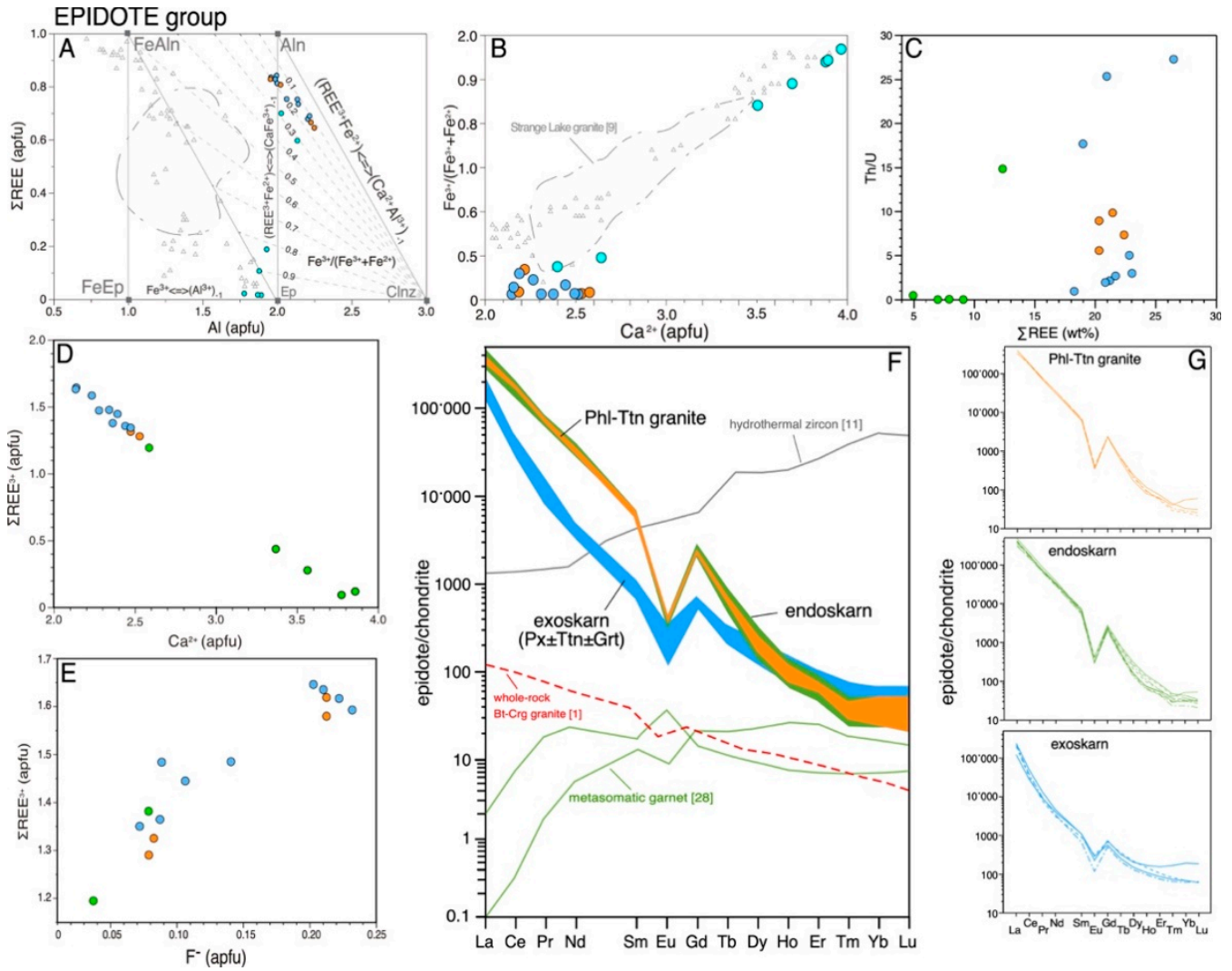

Figure 12. Mineral chemistry of metasomatic epidote group minerals from the granite and the exoskarn bodies. Color of dots and lines refer to same samples (see Figure 8F). (A) Diagram showing the possible element substitution mechanisms in the epidote group minerals, along with the classification scheme of [32] based on the $\mathrm{Fe}^{3+} /\left(\mathrm{Fe}^{3+}+\mathrm{Fe}^{2+}\right)$ ratio. (B) Ca vs. $\mathrm{Fe}^{3+} /\left(\mathrm{Fe}^{3+}+\mathrm{Fe}^{2+}\right)$ diagram, with allanite showing the lowest $\mathrm{Fe}^{3+} /\left(\mathrm{Fe}^{3+}+\mathrm{Fe}^{2+}\right)$ ratios. For comparison, data for epidote group minerals from the Corupá pluton [33] and Strange Lake granite [11] are also shown. (C-E) Mineral chemistry of metasomatic epidote and allanite showing a correlation between $\mathrm{REE}$, the $\mathrm{Th} / \mathrm{U}$ ratio, and the $\mathrm{F}$ content. (F) Chondrite-normalized REE pattern for allanite from phlogopite-titanite granite, endoskarn, and exoskarn bodies. (G) On the right a detailed chondrite-normalized REE pattern for allanite from each lithology are reported. For comparison, whole-rock (WR) data from reference [1]. Chondrite normalization values are taken from reference [25].

\subsubsection{HFSE-REE-Rich Minerals}

At Campiglia, it is possible to recognize several REE-HFSE-rich accessory minerals. First of all, both magmatic and metasomatic zircon and apatite (Figures 3-5) were observed. Zircon grains from the cordierite-biotite granite are commonly colorless and range from 50 to $250 \mu \mathrm{m}$ in diameter. Cathodoluminescence images show euhedral zircons, with typical oscillatory zoning and rare inherited cores. Metasomatic zircons resulted from the late metasomatism of calc-silicates, usually titanite (Figure $3 \mathrm{H}$ ). Zircon grains from metasomatic rocks are usually $<30 \mu \mathrm{m}$ in diameter, euhedral to subhedral, and homogeneous with minor oscillatory zoning and rare inclusions. They are usually found with other accessory minerals, such as fluorapatite, monazite, uraninite, and thorite (Figure $3 \mathrm{H}$ ). On the other hand, metasomatic fluorapatite from the phlogopite-titanite granite is linked to the metasomatized biotite. Indeed, fluorapatite, from the granitic rocks is commonly included in biotite as crystals of $<500 \mu \mathrm{m}$, (which is an uncommon size for magmatic fluorapatite) and grows along the biotite rim or along biotite cleavage planes. Smaller fluorapatite grains are included in the biotite (Figure 3G). Metasomatic fluorapatite is commonly euhedral to subhedral ( $<100 \mathrm{~s} \mu \mathrm{m}$ in length) and is associated with newly crystallized calc-silicates. The fluorapatite shows variable textures, such as 
complex zoning patterns, and homogeneous and oscillatory zoned grains. They are usually included in the phlogopite or fill cavities as aggregates with calcite, titanite, and diopside (Figure 5).

To a lesser extent, secondary crystals of monazite occasionally occur as a trail of zircon-monazite aggregates $(<15 \mu \mathrm{m})$ in metasomatic K-feldspar crystals [1]. Moreover, at the granite-host contact, the abundant fluorapatite is accompanied by the crystallization of HFSE-REE-rich calc-silicates, such as cheralite $\left(\mathrm{CaTh}\left(\mathrm{PO}_{4}\right)_{2}\right)$. This mineral is commonly replaced by secondary thorite-quartz pseudomorphs or thorite-apatite-zircon aggregates (Figure 3F).

\subsubsection{Fluorite}

Fluorite grains show variable size and colors and are observed as widespread, euhedral or interstitial, secondary grains in the metasomatized granite (frequently associated with sulfides), in the metasomatic bodies (exo- and endoskarn), and forming late quartz-fluorite and chlorite-sulfide-fluorite veins. In the metasomatized granite, fluorite commonly occurs along biotite cleavage planes, triggering an intense replacement by chlorite. Here, the fluorite grains are commonly associated with other metasomatic minerals, such as sulfides, usually growing along fractures. The alteration of accessory minerals into fluorite could produce structural deformation, resulting in violet to blackish fluorite crystals. Finally, fluorite-pyroxene pseudomorphs ( \pm quartz and calcite) replace a former metasomatic pyroxene-quartz-calcite association (Supplementary Table S1).

Colorless and white crystals were collected from late hydrothermal quartz-fluorite-sulfide-calcite veinlets, crosscutting the granite. Pink, violet, and dark violet crystals were collected from hydrothermal centimetric veins usually related to sulfides and accessory minerals (e.g., uraninite, cheralite, thorite). Finally, greenish crystals were collected from late hydrothermal veins in the endoskarn bodies. In the hydrothermal vein it is also possible to observe fluorite crystals characterized by a pink core, through to a green zone to a whitish rim. The analyzed fluorites do not show significant impurities, except for $\mathrm{Sr}$ (up to $150 \mathrm{ppm}$ ). On the other hand, the REE-profiles show two principal groups of fluorite (Figure 13). The green color group is rich in REE, with the LREE and HREE fractionated with respect to the middle REE. In contrast, the violet to colorless fluorites show a lower REE content and a flatter pattern, with an unusually positive $\mathrm{Y}$ anomaly. Dark violet or black fluorite is interpreted as violet fluorite damaged by radiation that was caused by U-bearing minerals included in some of the vein-type deposits. Thus, the color of the fluorite appears to reflect the $\mathrm{REE}(+\mathrm{Y})$ content, which is mainly control by the minerals associated with the fluorite.
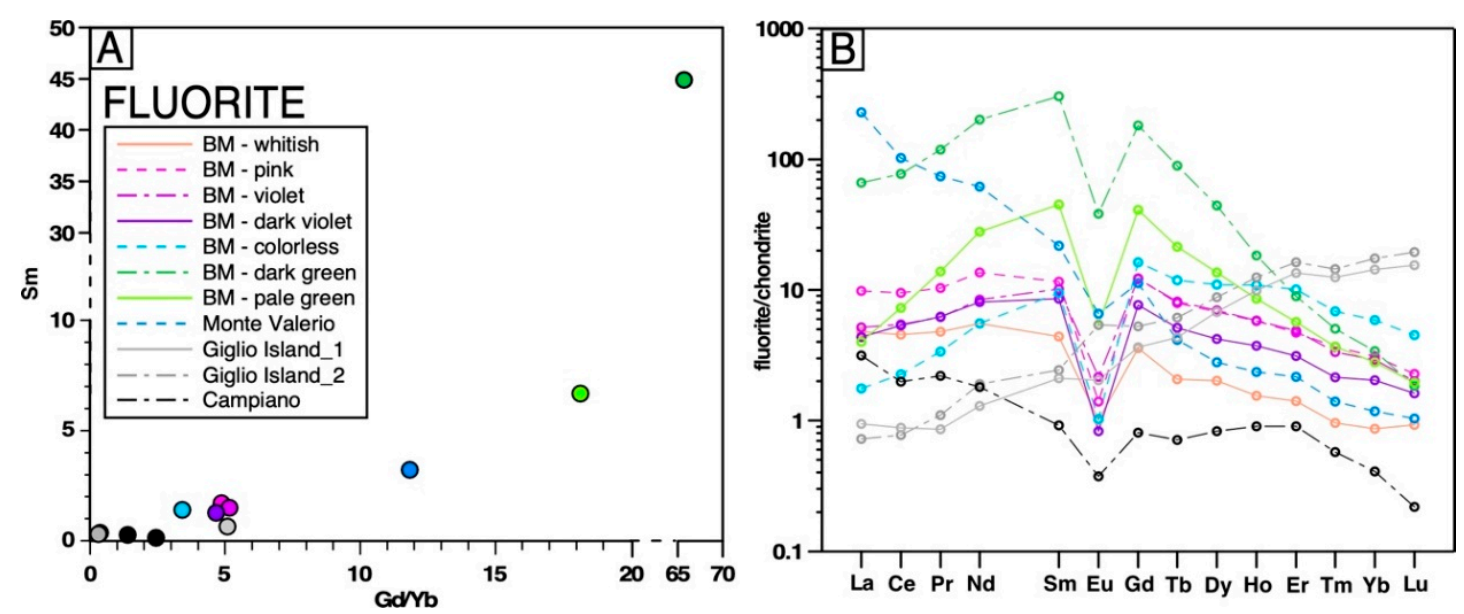

Figure 13. (A) Sm vs. Gd/Yb diagram showing an overall positive correlation, with higher values in the green crystals. (B) Chondrite normalized REE pattern for fluorite from the Campiglia system. Monte Valerio and Giglio Island fluorite are analyzed for comparison. Colors of symbols and lines correspond to fluorite crystal colors. Chondrite normalization values are taken from reference [25]. 


\subsubsection{Sulfides}

Multiple generations of sulfides are widespread throughout the system [1,18]. The main sulfides are pyrrhotite $(\mathrm{FeS})$, pyrite $\left(\mathrm{FeS}_{2}\right)$, sphalerite $(\mathrm{ZnS})$, chalcopyrite $\left(\mathrm{CuFeS}_{2}\right)$, and minor galena $(\mathrm{PbS})$. Single- and poly-phase sulphide grains occur (i) as isolated interstitial grains at the contact between magmatic minerals, (ii) in veins crosscutting mineral assemblages or along cleavage planes and fractures of fresh igneous minerals, and more rarely (iii) as inclusions near the margins of these same minerals. Individual grains are typically subhedral and vary from $\mu \mathrm{m}$ to $\mathrm{cm}$ in size and they are accompanied by crystallization of quartz, fluorite, as well as HFSE-REE and Th-U accessory minerals. Iron sulfides, chalcopyrite, and minor $\mathrm{Zn}-\mathrm{Pb}$ sulfides occurred as fracture and cavity infill. Numerous sulfides-quartz-calcite bearing veins (from a few millimeters to decimeters in width) are irregularly developed within the granitic rock, following the granite joints. Pyrrhotite-pyrite-sphalerite aggregates are widespread throughout the endoskarn and exoskarn system, filling open-spaces, forming veins, as isolated crystals, and showing multiple processes of intergrowth and mutual replacement. Late, low-temperature veins systems follow the granite body fracturation $[1,16]$. They are characterized by an abundance of chlorite, pyrite-sphalerite, calcite, quartz, violet fluorite, uraninite, and thorite.

\section{Discussion-Element Transfer Mechanisms During Metasomatic Processes}

Emplacement of igneous intrusions into cold carbonatic rocks will result in both loss of heat to the surrounding environment and transport of volatile components, which are a trigger for metasomatic processes [2]. Metasomatism involves major gain or loss of components, with element exchange between fluids and adjacent rocks along significant temperature and compositional gradients [2,3]. This generates new minerals replacing old ones and changes the bulk composition of the rock [6]. The BM peraluminous granite was affected by multiple metasomatic processes triggering significant element mass transfer. At the granite-marble contact, the interactions between metasomatic fluids, granite, and host carbonate resulted in significant replacement of the primary minerals by calc-silicates, oxides, HFSE-REE, and Th-U minerals, as well as the multiple generation of sulfides $[1,34]$ highlights that chemical zoning in metasomatic minerals, especially oscillatory zoning, is a common phenomenon interpreted as a primary growth texture. It expresses an interaction between the mineral surface and its environment. Indeed, during mineral growth, fluids when in contact with the mineral surface can promote some reactions, inhibit others, and generate a chemical potential gradient at the mineral surface $[4,6]$. A growing mineral may be surrounded by a thin layer depleted in those elements with the distribution coefficients favoring the solid phase, or by elements that are more rapidly taken up at the mineral surface [35]. However, if the mineral growth rate is constant and low, the chemical variations mostly depend on the fluid composition. These changes are indirectly responsible for changes in the growth rate. Thus, it is difficult to isolate a single event in an open system [35], like Campiglia.

\subsection{Potassic-Calcic Metasomatism}

After the emplacement, alkali-rich fluids strongly metasomatized the whole granite body [4]. The metasomatism of igneous minerals (biotite, plagioclase, and K-feldspar) produced distinct chemical exchanges (Figure 2). The content of some elements ( $\mathrm{Ti}, \mathrm{Al}, \mathrm{Si}$ ) remained unaffected after exchange reactions forming new phases, whereas other were added $(\mathrm{K}, \mathrm{Mg}, \mathrm{Ca}, \mathrm{Rb}, \mathrm{Ba}, \mathrm{Sr})$, and other $(\mathrm{Fe}, \mathrm{Mg}$, $\mathrm{Na}$ ) where scavenged from the granite. Plagioclase was replaced by K-feldspar, as a result of alkali ion exchange between a potassic fluid and feldspars (Figure 2). Metasomatic addition of $\mathrm{Mg}$ to biotite led to its replacement by phlogopite and chlorite. The concurrent loss of $\mathrm{Ti}, \mathrm{Fe}$, and $\mathrm{Al}$ contributed to the crystallization of new rutile and Al-rich titanite. The composition of the phyllosilicates (Figures 5 and 6; Table 1) yields important information on the metasomatism of the primary minerals, such as K-feldspar and biotite, and the mobility of $\mathrm{Fe}, \mathrm{K}, \mathrm{Al}, \mathrm{Mg}, \mathrm{Ti}, \mathrm{Ca}$, and $\mathrm{Si}$. This, in turn, provided constraints on the geochemical conditions prevailing during fluid-rock interaction in the granite. These data highlight that the exchange reactions occurred during the metasomatic replacement of biotite by phlogopite and 
chlorite, which involved TiMgFe ${ }^{-2},(\mathrm{OH}) \mathrm{F}^{-1}, \mathrm{KNa}^{-1}$ exchange vectors. Moreover, SEM-EDS analysis occasionally show Fe-enriched biotite crystals $(\mathrm{FeO}=35-40 \mathrm{wt} \%)$, that commonly has been interpreted to result from a K-Na exchange reaction during the process of alkali metasomatism [3]. Titanite and rutile have significant enrichment in $\mathrm{Nb}, \mathrm{Zr}$, and $\mathrm{Al}$, as well as similar $\mathrm{Nb} / \mathrm{Ta}$ ratios (Figures 8 and 9), allowing for a common origin to be inferred, as highlighted by petrographic evidence of mutual replacement (Figure 4). The compositional variations in titanite during this stage could be ascribed to an exchange reaction involving the $\mathrm{AlFTi}^{-1} \mathrm{O}^{-1}$ vector [36].

Concurrently, Ca activity is prominent along granite joints (endoskarn), at the pluton-host contact, and in the carbonate host (at the contact and along folded layers). In the area adjacent to the monzogranite-host contact, fluids are likely released from the host carbonate. On the other hand, endoskarn bodies within the granite and far from the contact with the carbonate, are affected by metasomatism from Ca-rich fluids possibly released by a deeper, not exposed mafic source. Reactions involving the addition of $\mathrm{Ca}$ and $\mathrm{Mg}$, together with the exchange of $\mathrm{Fe}, \mathrm{Ti}, \mathrm{Si}, \mathrm{Al}$, and trace elements indicate metasomatism of the original rocks and the crystallization of new calc-silicates, aluminosilicates, and REE-HFSE phases (Figures 2 and 3). Granite minerals are replaced by a diopside + titanite + phlogopite + epidote \pm apatite \pm zircon assemblage, while the carbonate country rock, originally consisting of calcite and minor dolomite and phyllosilicates, resulted in the crystallization of diopside + (hydrogrossular)garnet + vesuvianite + epidote + allanite + titanite + phlogopite \pm scapolite \pm apatite \pm zircon \pm cheralite. These processes highlight the exchange of major and trace elements between fluids, metasomatized granite, and host carbonate. Moreover, the distribution and density of the new minerals reflect the local composition of the host carbonate. For example, phlogopite crystallization is prominent along folds in the marble, characterized by a greater abundance of marl impurities (Mg-rich phyllosilicates).

This initial stage is also characterized by the partial metasomatism of accessory minerals, strongly included in biotite as usually observed in igneous rocks. Thus, accessory minerals control the total amount of REE and most of HFSE. Magmatic fluorapatite and monazite are mostly metasomatized, generating mobilization of P, REE, and Th and other trace elements (Figures 2 and 3F-G). The exchange reactions with Ca-rich fluids provoked the crystallization of secondary fluorapatite in the metasomatized granite, and the secondary crystallization of trails of zircon-monazite aggregates $(<15 \mu \mathrm{m})$ in the metasomatic K-feldspar crystals [1]. At the granite-marble contact, the increasing activity of Ca-rich fluids resulted in the abundant crystallization of fluorapatite, as well as HFSE/REE rich calc-silicates, such as cheralite (Figure 3F). At the same time, zoning patterns in the newly formed calc-silicates show increasing Th, U, HFSE, and REE toward the rims, which support the continuation of exchange reactions between the rocks and metasomatic fluids in time.

\subsection{Acidic Metasomatism-Declining Ca-Activity and Increasing F-Activity}

The increase in F-activity combined with the continuous crystallization of calc-silicates (Ca sequestration) enhance the acidity of the fluids responsible for the metasomatism of both HFSE/REE magmatic minerals and metasomatic calc-silicates, resulting in the mobilization of REE/HFSE [1]. Textural evidence indicate that $\mathrm{F}$ addition occurred during a late metasomatic stage. This is indicated by fluorite-rich late pseudomorphs after calc-silicate minerals, late fluorite crystals in tight spatial relation with intra-crystalline chlorite layers in phlogopite, $\mathrm{F}$ enrichment toward the rims in metasomatic vesuvianite, and late fluorite-rich veins (Figure 3) [1].

Acidic metasomatism coupled with HFSE/REE redistribution [1] is manifested by the following textures: (i) titanite, epidote, allanite, vesuvianite, and garnet with reaction and growth zoning characterized by the common increase, from core to rim, of HFSE (i.e., $\mathrm{Nb}, \mathrm{Ta}, \mathrm{Zr}$ ), LREE, Th, and $\mathrm{U}$, as well as $\mathrm{Zn}, \mathrm{Sn}$, and Sb (Figure 10); (ii) epidote progressively replaced by Ce-La-rich allanite, suggesting REE vs. Al and Ca vs. an Fe exchange reaction (Figure 12); (iii) dissolution/replacement reactions of pre-existing calc-silicates by secondary fluorapatite, zircon, thorite, and uraninite, usually mantling or in close spatial relation with the host calc-silicate (Figure 3); and (iv) the 
pseudomorphic replacement of cheralite by thorite-quartz aggregates, and diopside-quartz-calcite by clinopyroxene-fluorite-quartz-calcite aggregates (Figure 3). The calc-silicates crystallized during this late-stage show a positive correlation between $\mathrm{F}$, structure-forming elements, REE content, and Th/U ratio (Figures $8 \mathrm{D}, 11$ and 12E), supporting the ability of F-rich fluids to enhance the exchange of these components. Moreover, the widespread crystallization of fluorite indicates the importance of the F activity during the whole metasomatic process(es) (Figure 13).

\subsection{Footprints of Fluid-Rock Element Transfer in Mineral Zoning}

LA-ICP-MS and electron microprobe data of representative rock-forming minerals from Campiglia allow for the identification of physico-chemical variations of the hydrothermal fluids activating the metasomatic processes. Changes in mineral composition or element ratios reflect the crystallization/dissolution/replacement of different phases. For example, variations in the REE patterns observed in several minerals can be interpreted as reflecting progressive processes of metasomatism and crystallization from the fluid with a variable LREE/HREE ratio or a concurrent growth of minerals characterized by specific REE partition coefficients. Insights into the evolution of the metasomatic fluid composition can be gained by comparing mineral compositions and zoning in a relative chronology framework, although discriminating between phases crystallized during the K-Ca stage or later, under more acidic conditions, can be challenging.

\subsubsection{Links Between Concurrently Growing Minerals During Metasomatism}

Most of the metasomatic minerals show enrichment in Al, Sr, Ba, LREE, HFSE, Zr, Th, U, and Sn during growth. Fluorine shows unusually high concentrations in most of the newly crystallized minerals, which define a common positive correlation with the REE content (see Figures 8, 11 and 12). Usually, LREE are more enriched with respect to HREE, according to their relative mobility, with the former more mobile at high temperature and the latter more mobile at low temperature [37].

Titanite is the most representative metasomatic mineral observed throughout the whole system (granite, endoskarn, and exoskarn). Since mineral-fluid partition coefficients for REE in titanite do not vary significantly from LREE to HREE [38], the distribution of these elements in the titanite reflects their availability in the formation environment. Titanite, as well as rutile and phlogopite, show significant abundances in $\mathrm{Nb}$ (up to $2.8 \mathrm{wt} \%$ ) and Ta, indicating that the mobilization of HFSE was initiated from the beginning of the K-Ca metasomatism (Figures 8 and 9). The REE pattern for titanite crystals from the granite, the endoskarn, and veins are shown in Figure 8. All the REE-patterns highlight La-Ce depletion, that is ascribable to the concurrent crystallization of the allanite (Figure 8). Titanite from both the slightly altered biotite-cordierite and phlogopite-titanite granite show two different REE patterns. The group characterized by a granite-like pattern could have formed during the early stages of metasomatism, while the group characterized by an overall higher REE content and strong depletion in HREE, likely crystallized later, under more acidic conditions linked to a higher REE availability and competed with concurrently crystallizing metasomatic zircon. Euhedral titanite crystals from veins and endoskarn bodies show granite-like patterns, which are characterized by a moderately fractionated profile with an Eu negative anomaly. This suggests that they crystallized in the absence of competing zircon, which is supported by the lack of zircons in the veins (Figure 8).

Generally, allanite-epidotes show strongly fractionated REE profiles, with a spoon-shaped HREE profile and a negative Eu anomaly pointing out competition with zircon. Nevertheless, allanite from the diopside-garnet-vesuvianite-bearing exoskarn is characterized by a less-fractionated pattern (Figure 12), lending support to crystallization in conditions of high REE availability yet in possible competition with garnet (Figure 12). Thus, the variability in REE-patterns could be controlled by (i) overall co-crystallization of zircon and (ii) co-crystallization of garnet limited to the exoskarn.

REE are commonly a minor constituent in vesuvianite but can reach significant values (here show values of LREE up to $2 \mathrm{wt} \%$ ). There are three possible reactions involving the incorporation of REE in vesuvianite. (i) It is possible to exclude the coupled substitutions $\mathrm{REE}^{3+}+\mathrm{Mg} \rightarrow \mathrm{Ca}+\mathrm{Al}$ and $\mathrm{Mg}+\mathrm{Ti}$ 
$\rightarrow 2 \mathrm{Al}$, considering that the REE-rich vesuvianite contains $\mathrm{Al}$ [27]. (ii) Another possible mechanism involves the substitution of $\mathrm{O}^{2-}$ for $\mathrm{OH}^{-}$, however, there are insufficient data on the $\mathrm{OH}^{-}$contents of vesuvianite to test the importance of this substitution. (iii) The last process proposed by [27] are the coupled substitutions $\mathrm{REE}^{3+}+\mathrm{Na} \rightarrow 2 \mathrm{Ca}$ and $\mathrm{Na}+\mathrm{Ti}^{4+} \rightarrow \mathrm{Ca}+\mathrm{Al}$, which are the most likely.

Figure 11 shows intriguing chondrite-normalized REE patterns. Indeed, vesuvianite from the diopside-bearing exoskarn show REE enrichment with constant depletion from LREE to HREE, and with a strong negative $\mathrm{Eu}$ anomaly $\left(\mathrm{Eu} / \mathrm{Eu}^{*}=0.31-0.44\right)$. Conversely, vesuvianite from the vesuvianite-garnet exoskarn shows profiles characterized by an overall spoon-shaped pattern, stronger LREE fractionation, and a prominently positive Eu anomaly $\left(\mathrm{Eu} / \mathrm{Eu}^{*}=1.9-8.3\right)$. These data could be explained by the concurrent crystallization of garnet, responsible for the overall REE decrease, focused on the middle REE. A role for allanite co-crystallization could be read in a strong decrease in the LREE, with respect to vesuvianite from the exoskarn, and in the concomitant positive Eu anomaly.

Phosphates (mostly fluorapatite) are interpreted to control the mobility of P, REE, and HFSE from the beginning of the metasomatism. Indeed, the granite is characterized by significant reworking of magmatic monazite and fluorapatite, and the whole system is characterized by newly crystallized fluorapatite, while the endoskarn and exoskarn commonly show abundant crystallization of fluorapatite and minor cheralite grains.

Titanite, vesuvianite, and epidote(s) show a general increase in the REE content from core to rim, indicating the progressive mobilization/availability of these components (Figures 8 and 11, and Figure 12). Titanite shows a negative correlation of the total REE content with U/Th ratio from core to rim, whereas the opposite is true for vesuvianite and allanite. These data reflect the differential mobilization of $U$ and $T h$ in the different environments (with the latter more easily mobilized), thus pointing out that these minerals did crystallize from a hydrothermal fluid with an evolving U/Th ratio. Moreover, the growing abundance of Th in the fluids is probably controlled by the exchange of Th between the fluid and accessory minerals, either magmatic (monazite, fluorapatite, zircon) or newly crystallized, during the K-Ca metasomatic stage (cheralite). The core-to-rim increase of the REE content in epidote, and its mantling by allanite, testify to the evolution of the metasomatic fluid chemistry, which is characterized by increasing availability of REE.

The fluorite composition shows two different REE pattern groups (Figure 13). The first is characterized by a strong enrichment in the middle REE and depletion in the HREE (green crystals), while the second is characterized by a flatter pattern with a slight depletion in the HREE (white-violet-pink and colorless crystals). Thus, a correlation exists between color and the REE pattern. Green crystals of fluorite show the highest content of REE with a strong enrichment in the middle REE, compared to violet crystals, which show flatter patterns. The green crystals are usually spatially related with late quartz-chlorite-sulfide veins, indicating late circulation of HFSE and REE. Moreover, the anomalously high $\mathrm{Y}$ content is common and interpreted to reflect crystallization from enriched hydrothermal fluids after extended fluid-rock interaction, as observed in other contexts $[39,40]$. Fluorite occurs also in other environments affected by hydrothermal activity in Tuscany [41]. Green fluorite from the nearby Monte Valerio Fe-Sn(-W) deposit has a comparable HREE distribution, but a strong enrichment and fractionation of LREE, suggesting different competing phases during formation of the Campiglia fluorite. Colorless fluorite from the Giglio Island hydrothermal pyrite mineralization shows a completely different REE fractionation, indicating a very different fluid composition/mineral competitor. On the other hand, fluorite from the Campiano pyrite mineralization has patterns more similar to the Monte Valerio fluorite, even if it is at lower concentrations.

In summary, the composition and zoning of metasomatic minerals reflects the complex interplay between the evolution of the fluid composition and the co-crystallizing phases, which implies that all the mineral data have to be accounted for in a unique system. 


\subsubsection{Links Between REE-HFSE Mobilization and Fluorine Activity}

The controlling factors for REE mobilization are the formation of aqueous chloride complexes $\left(\mathrm{REECl}^{2+}, \mathrm{REECl}^{2+}\right)$, whereas the mobility of Zr mostly depended on the formation of hydroxy-fluoride complexes such as $\mathrm{ZrF}(\mathrm{OH})_{3}$ and $\mathrm{ZrF}_{2}(\mathrm{OH})_{2}$ [42-44]. This process is enhanced by low $\mathrm{pH}$ values, which depends on the initial concentrations of $\mathrm{Cl}$ and $\mathrm{F}$, temperature (decreasing $\mathrm{T}$ correspond to increasing supply of $\mathrm{H}^{+}$), and the rate of fluid-rock exchange reactions. Usually, mineral solubility increases with increasing temperature, though $\mathrm{Zr}$ is mostly mobilized at lower temperatures [42,43]. Thus, the metasomatic crystallization of REE-bearing minerals could be explained by the scarcity of REE-transporting ligands, such as chloride, coupled with the abundance of fluoride and phosphate, which likely play an important role as depositional ligands [45]. The concomitant crystallization of minerals with contrasting LREE/HREE partition coefficients produced strong variabilities in the REE-patterns of the co-crystallizing minerals. The increasing availability of $F$ ions, previously dropped by $\mathrm{Al}^{3+}$ released during $\mathrm{K}-\mathrm{Ca}$ metasomatism of plagioclase $\left(\mathrm{AlF}^{2+}\right)$, is possibly promoted by $\mathrm{AlF}^{2+}$ breakdown due to increasing fluid acidity. This process releases $\mathrm{F}$ in sufficient concentrations to promote Zr solubility as hydroxy-fluoride complexes at very low $\mathrm{pH}$ [37].

Light REE mobility at Campiglia was largely controlled by the stability of allanite-(Ce, La) and vesuvianite, for which thermodynamic data are unfortunately scarce. The same uncertainty occurs in evaluating HREE mobility, which was likely controlled by zircon, for which HREE partitioning into hydrothermal fluids is poorly constrained. Thus, the strong HREE depletion observed in the main metasomatic minerals, chiefly titanite and allanite, could be controlled by the solubility of zircon, which is enhanced by low temperature and $\mathrm{pH}$, as well as a high $\mathrm{F}$ concentration. It is therefore suggested that the F-activity increased in the metasomatic fluids during metasomatism. Indeed, F-rich fluids are extremely corrosive and extended interaction with the rocks could lead to mobilization/exchange of HFSE, REE, Zr, Th, U, and base metals [42]. The common co-precipitation of fluorite and HFSE-REE minerals, as well as Th-U minerals, supports the role of fluoride as depositional ligand for these elements. Moreover, the increasing activity of F-rich fluids is confirmed by fluorite-bearing, fine-grained pseudomorphs replacing former calc-silicates (Figure 3E). Another supporting evidence is the high content of $\mathrm{F}$ in several metasomatic minerals (fluorapatite, vesuvianite, phlogopite, allanite, and titanite). Finally, fluorite crystallization is characteristic of the metasomatism in general with inclusions and veins filling fractures (Figures 3 and 4).

Metasomatic transport of $\mathrm{Zr}$ at Campiglia is attested to by the scattered occurrence of zircon grains in the exoskarn bodies (Figure 3; [1]). Indeed, there are few possible processes could explain the origin of these zircons. These include inheritance of detrital zircons from the carbonate host rock, fluids transport of magmatic zircon from the intrusion to the metasomatic assemblage, or direct precipitation from a metasomatic fluid [46,47]. At Campiglia, there is no evidence of zircon inheritance from the host rock (lacking zircon), or transport from the granitic intrusion. In contrast, there is evidence that support a direct precipitation from hydrothermal fluids. Indeed, zircon grains from the exoskarn bodies are commonly euhedral with a diameter of $<40 \mu \mathrm{m}$, and a morphology typical of flux-grown zircons formed in hydrothermal environments [48-50]. Most of the zircon grains are intergrown with apatite and their abundance increases at the granite-host transition, where the abundance of Ca-rich fluids could be responsible for the local P precipitation as suggested by [51]. The joint occurrence of metasomatic zircon and fluorapatite highlights the mobility of $\mathrm{Zr}$ and $\mathrm{P}$ (commonly not very mobile) in metasomatic fluids in the Campiglia system.

In conclusion, new metasomatic mineral associations, resulting from continuous exchange reactions as well as the addition and loss of components, highlight the mobilization of a great number of elements. Even elements considered poorly mobile, such as Ti, Zr, Th, REE, and HFSE, underwent at least some local mobilization, indicating transport via acidic fluids. Indeed, the abundance of HFSE-REE and Th-U minerals, the zoning/replacement of calc-silicates, and the common occurrence of fluorite-bearing, late pseudomorphs, support the exchange of HFSE, REE, and other components between the granite, Ca-F-rich fluids, and host carbonates. 


\section{Nature and Source of Metasomatic Fluids at Campiglia}

At Campiglia, a whole set of field relationships and geochemical data, despite the lack of stable isotope and fluid inclusion studies, allows for a concrete speculation to be made regarding the origin of the metasomatic fluids. Multiple sources are likely the best option (Figure 14). The potassic main feature of the metasomatic fluids and the peraluminous character of the magma would lead to contrasting expectations for the metasomatic products. Indeed, metasomatic processes related to peraluminous plutons like BM commonly produce skarn-related Sn deposits [51]. On the other hand, Ca-Fe skarns are most commonly related to metaluminous plutons that have the thermal and chemical potentials to trigger metasomatic processes leading such skarns, and which usually show a clear geochemical mantle signature and relatively little interaction with continental sedimentary material [51]. Pyroxene and garnet-pyroxene skarns typically result from the interaction between metasomatic fluids released by a mafic source and a carbonatic host rock [51].

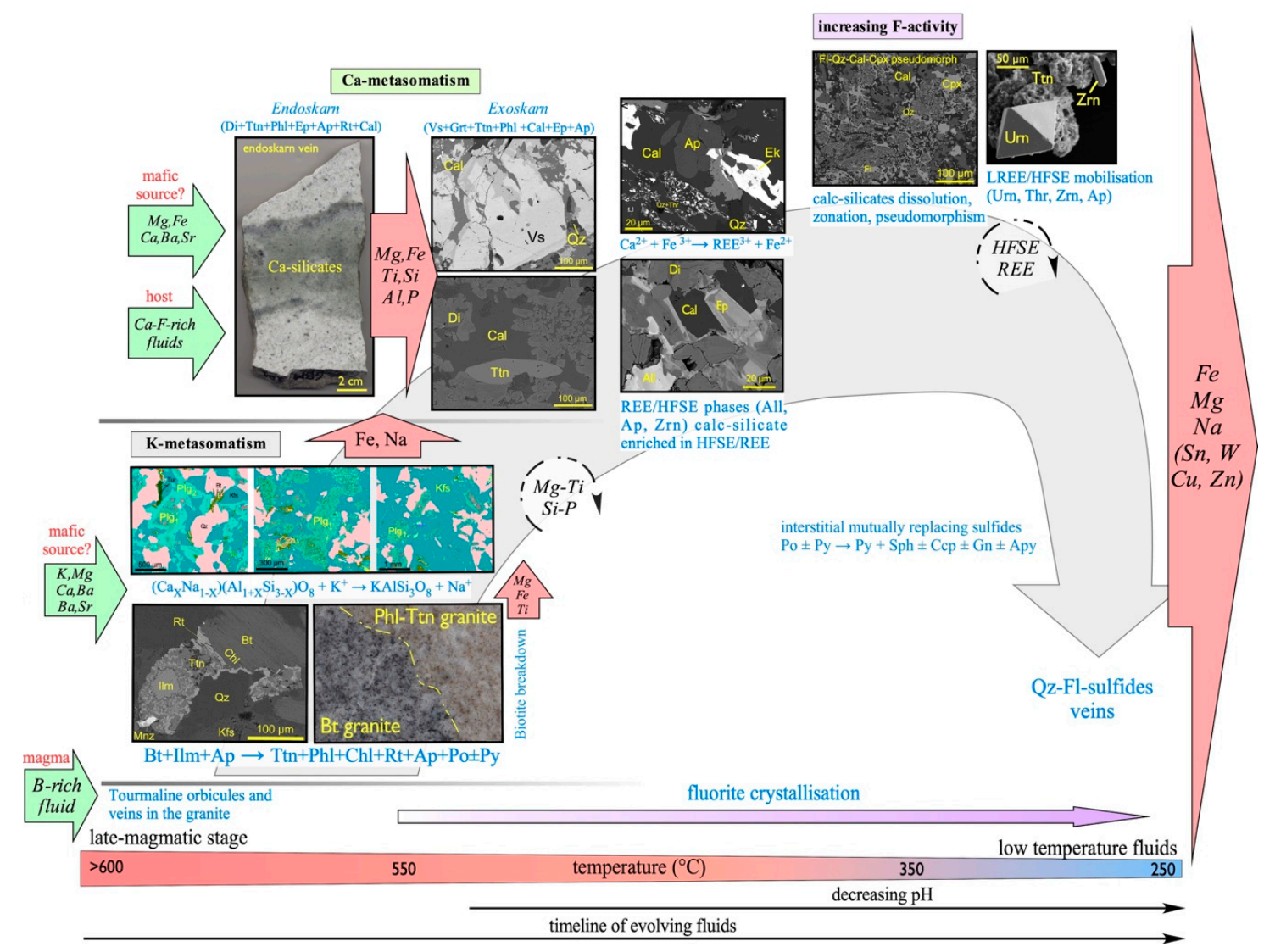

Figure 14. Schematic model for the progressive element mobilities reconstructed for the Campiglia metasomatic system, showing the main mechanism responsible for the selective mobilization of elements, and indicating the possible litho-geochemical vectors for the metasomatic processes. For mineral abbreviations [20], see Table 1 .

At Campiglia, the BM peraluminous pluton is indeed associated with $\mathrm{Sn}-\mathrm{Fe}(-\mathrm{W})$ deposits of the nearby Monte Valerio area (Figure 1), which indicates a general exchange/mobilization of Fe, Sn, and $\mathrm{W}$ between the granite and metasomatic fluids. Nevertheless, the BM exoskarn and the skarn at the nearby Temperino mine (Figure 1), despite the differences in the main mineral parageneses (K-feldspar, phlogopite, titanite, diopside, vesuvianite, allanite, and grossular at BM [1]; hedenbergite, ilvaite, johannsenite for Temperino [18]), both require fluids issuing from mafic magmatic systems. Additionally, the potassic nature of metasomatism at BM resembles the K-rich nature of the mafic magma occurring at Temperino. There, the $\mathrm{Zn}-\mathrm{Pb}$ skarn predates the $\mathrm{Fe}-\mathrm{Cu}$ mineralization and formed 
as a distal skarn at about $1 \mathrm{~km}$ above the top of the main BM intrusion [18]. Thus, the emplacement of a mafic magma during this first stage is not required, given that deep-seated hydrothermal fluids can move independently from the melt.

Detailed geo/minero-chemical data obtained from the Campiglia area support the general gain of $\mathrm{K}, \mathrm{Ca}, \mathrm{Fe}, \mathrm{Mg}, \mathrm{Ba}, \mathrm{Rb}$, and $\mathrm{Sr}$ [this work, 1]. Thus, fluids released from an external source must be invoked to explain the high $\mathrm{Rb}, \mathrm{Ba}, \mathrm{K}$, and $\mathrm{Mg}$ concentrations, considering that the country rocks have low abundances of these elements (see whole-rock gain/loss diagrams in reference [1]). Moreover, assimilation of marble country rocks can account for the high $\mathrm{Ca}$ and Sr contents only in granite samples very close to the granite-marble interface. In fact, this assimilation is limited by both the amount of heat available and the surface area of the assimilated rocks. Thus, a major input of Ca from an external source is suggested by the occurrence of endoskarn bodies also at depth (borehole data) [1]. Furthermore, data from boreholes highlight the loss from the granite of $\mathrm{Mg}, \mathrm{Cr}, \mathrm{Ni}, \mathrm{Nb}$, and Sr with increasing depth. In this context, noteworthy is the high content of metals in the original granite if compared with crustal values ( $\mathrm{Sn}=7-12$ vs. $\sim 2 \mathrm{ppm}$; $\mathrm{W}=$ up to $50 \mathrm{vs} .1 .1 \mathrm{ppm} ; \mathrm{Tl}=\sim 2 \mathrm{vs}$. 0.5 ppm; [52]). Thus, during metasomatism, the granite did loose significant amounts of metals, such as $\mathrm{Cu}, \mathrm{Zn}, \mathrm{Ni}, \mathrm{Mo}, \mathrm{Sb}$, and Tl, though mainly Sn, W, and Zr [11].

In summary, a mafic reservoir is inferred to have been active since the emplacement of the BM granite, as supported by comparable U-Pb high-precision ages from zircon [14,15]. Thus, it is proposed that hydrothermal fluids moving independently from a mafic magma and may have been responsible at least part for the metasomatic processes observed in the Campiglia system.

\section{Summary and Conclusions}

The Botro ai Marmi (BM) granitic pluton underwent intense metasomatism during post-magmatic fluid-rock interaction processes (Figure 14). Petrographic and geochemical characteristics of the metasomatic products support that the mobility of HFSE, U, Th, and REE started during the K-Ca metasomatic stage and increased during the following acidic stage. Calc-silicates and accessory minerals formed, which show a progressive enrichment in HFSE and LREE. These phases exhibit complementary trace element patterns. The contribution of F-rich fluids enhanced the acidic metasomatism of the calc-silicates, which resulted in the replacement of the major elements ( $\mathrm{Ti}, \mathrm{Ca}, \mathrm{Fe}, \mathrm{Al}$ ) with HFSE and REE and the crystallization of new HFSE-REE minerals. Thus, Ca-F-rich fluids triggered the mobilization of HFSE, REE, and other trace elements down to low temperatures. The close spatial association of strongly altered and least altered calc-silicates indicates that the REE and HFSE were mobile on a local scale (10s of meters). It appears that the REE were removed at some localities and re-precipitated within a few meters.

In conclusion, the selective mobilization of HFSE-REE-U-Th was related to shifting fluid composition, $\mathrm{pH}$, and temperature. This study emphasizes the importance of relating field studies to petrographic observations and detailed mineral chemical analysis and shows how such interconnections can lead to the genesis of a litho-geochemical model for element mobilization in a crustal magmatic-hydrothermal environment.

Supplementary Materials: The following are available online at http://www.mdpi.com/2075-163X/9/11/682/s1, Table S1. Major $(\mathrm{wt} \%)$ and trace $\left(\mathrm{ppm}=\mu \mathrm{g} \cdot \mathrm{g}^{-1}\right.$ ) elements composition resulted from selected electron microprobe analyses for minerals from the Botro ai Marmi mine. File S1: Detailed description of Materials and Methods [53-56].

Author Contributions: Conceptualization, G.P., A.D., and S.R.; Methodology, G.P. and M.P.; Software, G.P. and M.P.; Validation, G.P., A.D., and S.R.; Formal Analysis, G.P. and M.P.; Investigation, G.P. and M.P.; Resources, S.R.; Data Curation, G.P., A.D., S.R., and M.P.; Writing-Original Draft Preparation, G.P. and S.R.; Writing-Review \& Editing, G.P., A.D., S.R., and M.P.; Visualization, G.P., S.R., and A.D.; Supervision, S.R., A.D., and M.P.; Project Administration, S.R. and A.D.; Funding Acquisition, S.R.

Funding: This work has been carried out as part of the Ph.D project of G.P. at the University of Pisa, with the support of the Progetto di Ricerca di Ateneo (PRA_2016_33). 
Acknowledgments: Thanks to K. Kouzmanov for support with QEMSCAN acquisition and to M. D'Orazio for help during LA-ICP-MS analysis. I thank three anonymous reviewers for their constructive comments on the manuscript, which significantly improved the presentation of this study.

Conflicts of Interest: The author declares no conflict of interest.

\section{References}

1. Paoli, G.; Dini, A.; Rocchi, S. Footprints of element mobility during metasomatism linked to a late Miocene peraluminous granite intruding a carbonate host (Campiglia Marittima, Tuscany). Int. J. Earth Sci. 2019, 108, 1617-1641. [CrossRef]

2. Pirajno, F. Hydrothermal Processes and Mineral Systems; Springer: Berlin, Germany, 2009.

3. Pirajno, F. Effects of metasomatism on mineral systems and their host rocks: Alkali metasomatism, skarns, greisens, tourmalinites, rodingites, black-wall alteration and listvenites. In Metasomatism and the Chemical Transformation of Rock: The Role of Fluids in Terrestrial and Extraterrestrial Processes; Springer: Berlin/Heidelberg, Germany, 2013; pp. 203-251.

4. Harlov, D.E.; Austrheim, H. Metasomatism and chemical transformation of Rock: Rock-mineral-fluid interaction in terrestrial and extraterrestrial environments. In Metasomatism and the Chemical Transformation of Rock. Lecture Notes in Earth System Sciences; Springer: Berlin/Heidelberg, Germany, 2013; pp. 1-16.

5. Mathieu, L. Quantifying hydrothermal alteration: A review of methods. Geosciences 2018, 8, 245. [CrossRef]

6. Putnis, A.; Austrheim, H. Fluid-induced processes: Metasomatism and metamorphism. Geofluids 2010, 10, 254-269.

7. Jamtveit, B.; Wogelius, R.A.; Fraser, D.G. Zonation patterns of skarn garnets-Records of hydrothermal system evolution. Geology 1993, 21, 113-116. [CrossRef]

8. Taghipour, B.; Moore, F.; Mackizadeh, M.A.; Taghipour, S. Hydrothermal garnet in porphyry copper related skarn deposits, Ali-Abad, Yazd Province, Iran. IJST 2013, A1, 11-22.

9. Jiang, S.Y.; Wang, R.C.; Xu, X.S.; Zhao, K. Mobility of high field strength elements (HFSE) in magmatic-, metamorphic-, and submarine-hydrothermal systems. Phys. Chem. Earth Parts A B C 2010, 30, 1020-1029. [CrossRef]

10. Gieré, R. Hydrothermal mobility of Ti, Zr and REE: Examples from the Bergell and Adamello contact aureoles (Italy). Terra Nova 1990, 2, 60-67. [CrossRef]

11. Gysi, A.P.; William-Jones, A.E.; Collins, P. Lithogeochemical vectors for hydrothermal processes in the Strange Lake peralkaline granitic REE-Zr-Nb deposit. Soc. Econ. Geol. 2016, 111, 1241-1276. [CrossRef]

12. Pinarelli, L.; Poli, G.; Santo, A. Geochemical characterization of recent volcanism from the Tuscan Magmatic Province (Central Italy): The Roccastrada and San Vincenzo centers. Period. Miner. 1989, 58, 67-96.

13. Leoni, L.; Tamponi, M. Thermometamorphism in the Campiglia Marittima aureole (Tuscany, Italy). J. Miner. Geochem. 1991, 4, 145-157.

14. Paoli, G.; Rocchi, S.; Dini, A.; Vezzoni, S.; Schaltegger, U.; Ovtcharova, M. The Plutonic-Subvolcanic-Volcanic Connection in the Long-Lived Campiglia Marittima Igneous System (Tucany, Italy): A Zircon CA-ID-TIMS Dating Study; SIMP-SGI-SOGEI-AIV: Pisa, Italy, 2017; p. 387.

15. Paoli, G. Petrogeochemical and geochronological framework of element mobility during magmaticmetasomatic processes (Campiglia Marittima, Tuscany). Plinius 2018, 44, 67-71.

16. Fulignati, P. Hydrothermal fluid evolution in the Botro ai Marmi quartz-monzonitic intrusion, Campiglia Marittima, Tuscany, Italy. Evidence from a fluid-inclusion investigation. Miner. Mag. 2018, 82, 1169-1185. [CrossRef]

17. Borsi, S.; Ferrara, G.; Tongiorgi, E. Determinazione con il metodo K/Ar delle età delle rocce magmatiche della Toscana. Boll. Soc. Geol. Ital. 1987, 86, 403-411.

18. Vezzoni, S.; Dini, A.; Rocchi, S. Reverse telescoping in a distal skarn system (Campiglia Marittima, Italy). Ore Geol. Rev. 2016, 77, 176-193. [CrossRef]

19. Feldstein, S.N.; Halliday, A.N.; Davies, G.R.; Hall, C.M. Isotope and chemical micro-sampling: Constrains on the history of an S-type rhyolite, San Vincenzo, Tuscany, Italy. Geochim. Cosmochim. Acta 1994, 58, 943-958. [CrossRef]

20. Whitney, D.L.; Evans, B.W. Abbreviations for names of rock-forming minerals. Am. Mineralog. 2010, 95, 185-187. [CrossRef] 
21. Petrelli, M.; Laeger, K.; Perugini, D. High spatial resolution trace element determination of geological samples by laser ablation quadrupole plasma mass spectrometry: Implications for glass analysis in volcanic products. Geosci. J. 2016, 20, 851-863. [CrossRef]

22. Abdel-Rahman, A.F.M. Nature of biotites from alkaline, calc-alkaline and peraluminous magma. J. Pet. 1994, 35, 525-541. [CrossRef]

23. Deer, W.A.; Howie, R.A.; Zussman, J. An Introduction to the Rock-Forming Minerals; Prentice Hall: New York, NY, USA, 1992.

24. Farina, F.; Dini, A.; Innocenti, F.; Rocchi, S.; Westerman, D.S. Rapid incremental assembly of the Monte Capanne pluton (Elba Island, Tuscany) by downward stacking of magma sheets. Geol. Soc. Am. Bull. 2010, 122, 1463-1479. [CrossRef]

25. Sun, S.S.; McDonough, W.F. Chemical and isotopic systematics of oceanic basalts: Implications for mantle composition and processes. In Magmatism in the Ocean Basins. Geol. Soc. Lond. 2010, 42, 315-345.

26. Jochum, K.P.; Stolz, A.J.; Mcoirst, G. Niobium and tantalum in carbonaceous chondrites: Constraints on the solar system and primitive mantle niobium/tantalum, zirconium/niobium, and niobium/uranium ratio. Meteorit. Planet. Sci. 2000, 35, 229-235. [CrossRef]

27. Groat, L.A.; Hawthorne, F.C.; Ercit, T.S. The chemistry of vesuvianite. Can. Miner. 1992, 30, $19-48$.

28. Gaspar, M.; Knaack, C.; Meinert, L.; Moretti, R. REE in skarn Systems: A LA-ICP-MS study of garnets from the Crown Jewel gold deposit. Geochim. Cosmochim. Acta 2008, 72, 185-205. [CrossRef]

29. Einaudi, M.T.; Meinert, L.D.; Newberry, R.J. Skarn deposits. Econ. Geol. 1985, 75, 317-391.

30. Nakano, T.; Takahara, H.; Norimasa, N. Intracrystalline distribution of major elements in zoned garnet from skarn in the Chichibu mine, central Japan; illustration by color-coded maps. Can. Miner. 1989, 27, 499-507.

31. Meinert, L.D. Application of skarn deposit zonation models to mineral exploration. Explor. Miner. Geol. 1997, $6,185-208$.

32. Petrík, I.; Broska, I.; Lipka, J.; Siman, P. Granitoid allanite-(Ce): Substitution relations, redox conditions and REE distributions (on an example of I-type granitoids, Western Carpathians, Slovakia). Geol. Carpathica 1995, 46, 79-94.

33. Vlach, S. Structural and compositional variations of hydrothermal epidote-group minerals from a peralkaline granite, Corupá pluton, Graciosa Province, south Brazil. Acad. Bras. Cienc. 2012, 84, 407-425. [CrossRef]

34. Shore, M.; Fowler, A.D. Oscillatory zoning in minerals: A common phenomenon. Can. Miner. 1996, $34,1111-1126$.

35. Harlov, D.E.; Marschall, H.R. Mechanisms of metasomatic reactions. Miner. Pet. 2009, 95, 159-161. [CrossRef]

36. Markl, G.; Piazolo, S. Stability of high-Al titanite from low-pressure calcsilicates in light of fluid and host-rock composition. Am. Miner. 1999, 84,37-47. [CrossRef]

37. Gysi, A.P.; Williams-Jones, A.E. Hydrothermal mobilization of pegmatite-hosted REE and Zr at Strange Lake, Canada: A reaction path model. Geochim. Cosmochim. Acta 2013, 122, 324-352. [CrossRef]

38. Burt, D.M. Compositional and phase relations among rare earth element minerals. In Geochemistry and Mineralogy of Rare Earth Elements; Lipin, B.R., McKay, G.A., Eds.; Mineralogical Society of America: Chelsea, MI, USA, 1989; pp. 259-302.

39. Dill, H.G.; Hansen, B.T.; Weber, B. REE contents, REE minerals and $\mathrm{Sm} / \mathrm{Nd}$ isotopes of granite- and unconformity-related fluorite mineralization at the western edge of the Bohemian Massif: With special reference to the Nabburg-Wölsendorf District, SE Germany. Ore Geol. Rev. 2011, 40, 132-148. [CrossRef]

40. Munoz, M.; Premo, W.R.; Courjault-Radé, P. Sm Nd dating of fluorite from the worldclass Montroc fluorite deposit, southern Massif Central, France. Miner. Depos. 2004, 39, 970-975. [CrossRef]

41. Benvenuti, M.; Boschi, C.; Dini, A.; Ruggieri, G.; Arias, A. Geothermal resources, ore deposits and carbon mineral sequestration in hydrothermal areas of Southern Tuscany. Geol. Fieald Trips 2015, 7, 2-91.

42. Migdisov, A.A.; William-Jones, A.E.; Wagner, T. An experimental study of the solubility and speciation of the rare earth elements (III) in flouride-and chloride-bearing aqueous solutions at temperatures up to $300{ }^{\circ} \mathrm{C}$. Geochim. Cosmochim. Acta 2009, 73, 7087-7109. [CrossRef]

43. Migdisov, A.A.; Williams-Jones, A.E.; Van Hinsberg, V.; Salvi, S. An experimental study of the solubility of baddelite $\left(\mathrm{ZrO}_{2}\right)$ in fluoride-bearing solutions at elevated temperature. Geochim. Cosmochim. Acta 2011, 75, 7426-7434. [CrossRef]

44. Yang, X.M. Using Rare Earth Elements (REE) to decipher the origin of ore fluids associated with granite intrusions. Minerals 2019, 9, 426. [CrossRef] 
45. Migdisov, A.A.; Williams-Jones, A.E. Hydrothermal transport and deposition of the rare earth elements by fluorine-bearing aqueous liquids. Miner. Depos. 2014, 49, 987-997. [CrossRef]

46. Schaltegger, U. Hydrothermal zircon. Elements 2007, 3, 51. [CrossRef]

47. Deng, X.D.; Li, J.W.; Wen, G. U-Pb geochronology of hydrothermal zircons from the early Cretaceous iron skarn deposits in the Handan-Xingtai district, north China craton. Econ. Geol. 2015, 110, 2159-2180. [CrossRef]

48. Burakov, B.E.; Hanchar, J.M.; Zamoryanskaya, M.V.; Garbuzov, V.M.; Zirlin, V.A. Synthesis and investigation of Pu-doped single crystal zircon, $(\mathrm{Zr}, \mathrm{Pu}) \mathrm{SiO}_{4}$. Radiochim. Acta 2002, 90, 95-97. [CrossRef]

49. Yang, W.B.; Niu, H.C.; Shan, Q.; Sun, W.D.; Zhang, H.; Li, N.B.; Jiang, Y.H.; Yu, X.Y. Geochemistry of magmatic and hydrothermal zircon from the highly evolved Baerzhe alkaline granite: Implications for Zr-REE-Nb mineralization. Miner. Depos. 2014, 49, 451-470. [CrossRef]

50. Wan, B.; Xiao, W.; Zhang, L.; Han, C. Iron mineralization associated with a major strike-slip shear zone: Radiometric and oxygen isotope evidence from the Mengku deposit, NW China. Ore Geol. Rev. 2012, 44, 136-147. [CrossRef]

51. Meinert, L.D.; Dipple, M.G.; Nicolescu, S. World skarn deposits. Econ. Geol. 2005, 100, 299-336.

52. Taylor, S.R.; McLennan, S.M. The geochemical evolution of the continental crust. Rev. Geophys. 1995, 33, 241-265. [CrossRef]

53. Petrelli, M.; Caricchi, L.; Ulmer, P. Application of high spatial resolution laser ablation ICP-MS to crystal-melt trace ele- ment partition coefficient determination. Geostandards Geoanalytical Res. 2007, 31, 13-25. [CrossRef]

54. Longerich, H.; Jackson, S. Laser Ablation Inductively Coupled Plasma Mass Spectrometric Transient Signal Data Acquisition and Analyte Concentration Calculation. J. Analytical Atomic Spectrometry 1996, 11, 899-904. [CrossRef]

55. Tiepolo, M. In situ Pb geochronology of zircon with laser ablation-inductively coupled plasma-sector field mass spectrometry. Chem. Geol. 2003, 199, 159-177. [CrossRef]

56. Pearce, N.J.G.; Perkins, W.T.; Westgate, J.A.; Wade, S.C. Trace-element microanalysis by LA-ICP-MS: The quest for comprehensive chemical characterisation of single, sub-10 $\mu \mathrm{m}$ volcanic glass. Quat. Int. 2011, 246, 57-81. [CrossRef] 